\title{
Strategy for streamlining the workflow in architectural offices
}

Kajal Aggarwal $^{1}$, Noeen $\mathrm{Fatma}^{2}$, Anu Goyal ${ }^{3}$, Varad Singhal ${ }^{4}$, Shruti S. Nagdeve ${ }^{5 *}$

${ }^{1,2,3,4}$ Students, School of Planning and Architecture, New Delhi, India; ${ }^{5}$ Research Scholar, School of Planning and Architecture, New Delhi, India.

Email: ${ }^{1}$ kajaldm2k9@gmail.com, ${ }^{2}$ noeen.f24@gmail.com, ${ }^{3}$ anugoyal857@gmail.com, ${ }^{4}$ varad.singhal13@ gmail.com, ${ }^{5 *}$ shruti197phd18@spa.ac.in

Keywords

Streamline, Workflow, Efficient,

Architecture, Office.

\section{Article History}

Received on $14^{\text {th }}$ November 2021

Accepted on $17^{\text {th }}$ January 2022

Published on $5^{\text {th }}$ February 2022

\section{Cite this article}

Aggarwal, K., Fatma, N., Goyal, A.,

Singhal, V., \& Nagdeve, S. S. (2022).

Strategy for streamlining the workflow in

architectural offices. International Journal

of Students' Research in Technology \&

Management, 10(1), 15-37.

https://doi.org/10.18510/ijsrtm.2022.1012

\section{Copyright @ Author}

Publishing License

This work is licensed under a Creative Commons Attribution-Share Alike 4.0 International License

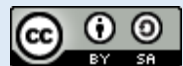

\section{INTRODUCTION}

A workflow is the complete or partial automation of a business process in which records, information, or tasks are passed from one entity to another for action according to a set of procedural rules. Workflow systems can be a beneficial tool, since they offer a way to automate and sustain organizational processes. Integrated technologies are essential for the management of collaborative processes and these needs are assisted by technology such as workflow systems. Workflow systems can replace existing paper-based and electronic flow and information stores, and provide flexibility to help business environment change. Proper use of workflow technology can provide companies with acompetitive advantage, or at least enable them to stay at a competitive level. Workflow can change the workplace positively, but before implementation, the effects of its use must be thoroughly researched and considered. The ability to automate highly repeat processing phases, which research work is known to entail, may further support the use of workflows and improve overall efficiency through apparent savings in time and effort.

Hence the question arises here to prepare a strategy for streamlining the work process by eliminating errors and improving workflow for increased efficiency and work output in an architectural practice.

This research aims to identify the current trends of workflow management prevalent in architectural offices; identifying the issues and associated problems, and finally develop an organized and streamlined workflow strategy. This has been defined with the following objectives:

1. To review the Tools of Management the seven Quality tools 7QC Tools.

2. To list the various systems of documenting and comparing their pros and cons.

3. To review the PMBOK (Project Management Body of Knowledge) Guidelines and standards for communication management and stakeholder management.

4. To assess the work flow:

- General system of workflow in architecture firms through online surveys. 


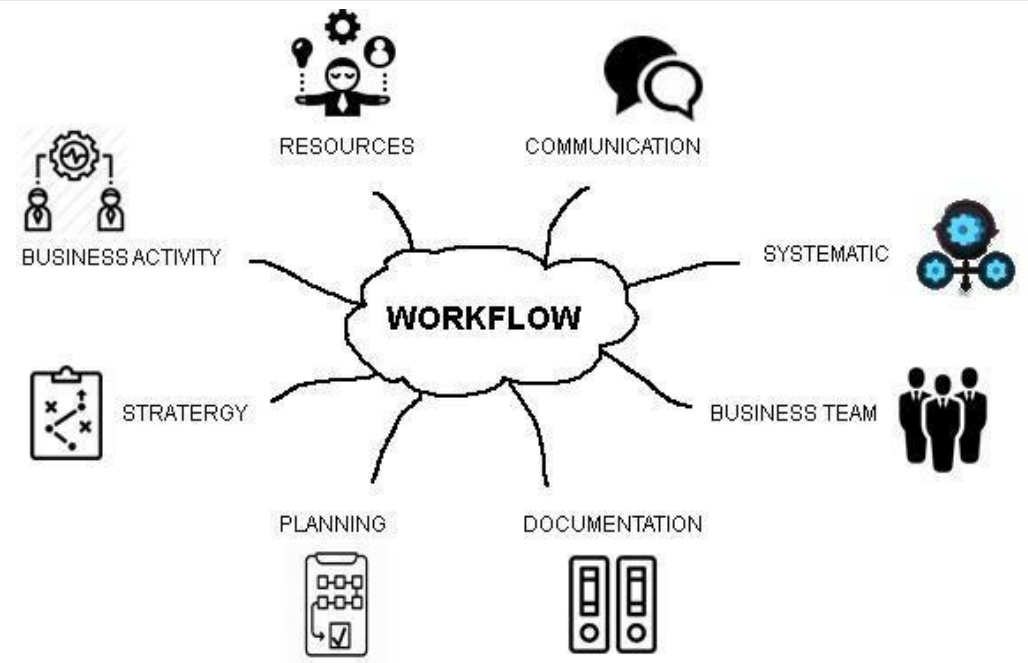

Figure 1: Factors Affecting Workflow

- Understanding the hierarchy within various departments in an architecture office and studying their relationships through online surveys.

- From personal experiences of internships of the authors.

- Study the initial procedure involved while the setting up of a firm.

5. To identify the bottlenecks and problems in the workflow.

6. To identify the relative importance of these problems.

7. To provide recommendations for the improvement of workflow strategies by eliminating the factors.

The research design is quantitative. The research instruments used for this study were a review of existing knowledge on the stakeholder and communication management, and seven quality tools and their application in the given situation. Thorough semi- structured expert interviews with practicing architects, and a survey with a target population practicing architects. A total of 34 respondents participated in the survey with a confidence interval of $\pm 16.8 \%$ meaning the results deviation fell under this range with a confidence level of $95 \%$. The survey questions corroborate with the expert interviews.

Data analysis from the survey is done by applying a cause analysis tool called Pareto (80-20) chart, which uncovered which of the problems are the vital few or the ones that are the most significant. Further, the vital few problems identified through Pareto Chart are investigated with the help of Ishikawa Diagram or the Fish-bone cause and effect diagram. The fishbone diagram used the 5 Whys analysis model to list all the possible root causes under each subcategory or "bone". This led us to the root cause of the problems which were identified. Thus, this made us reach our conclusion by recommending which causes need to be looked into the most to prevent the problems which cause the most damage.

The scope of this research is limited to strategies for streamlining the workflow within the office and the consultants for efficient, effective and mistake free work output. Since this research is pursued during the COVID-19 pandemic period, only online published research documents have been referred to, along with online surveys and interviews.

\section{Generic Workflow System}

1. System that do not "Talk To" One Another: More than $80 \%$ of business managers lack internal communications, which makes document monitoring difficult, warn versions and waste time copying and pasting or re-typing documents so that it cannot be identified when it is needed. This creates problem such as:
A. Sources of delays and duplicated tasks
B. Unnecessary steps or errors that cause extra work
C. Lack of quality standards or controls
D. Misinformation and undefined responsibilities

2. Uncertainty of Responsibilities: Often all the roles of a position may be unclear. The review of the workflow roles of the workers is helpful to all and clarifies it. When you introduce the workflow, there is no doubt who can do what at each project point. 
3. Efficient and Effective working with consultants: Time is too important to spend on unorganized bureau workflows. Workflows alter the behavior of businesses and individuals. The actual development of the technology is known and recorded reasonably well but its effective implementation is a different aspect. The technological workflow development and construction activities are typically completed. The issues that arise most during implementation tend to be more human than technical. If workflow systems are not introduced effectively, not only will money and time expended lose out, but companies' capability to stay competitive will also be limited.

4. New Demands, Insufficient Resources: Device and technology failure poses many challenges in streamlining working flow as devices grow stronger, local data processing and artificial intelligence capabilities minimize data transfer capacity, increase cloud reliance and offer more flexibility to employees.

5. Authenticity: Workers need to work for a company whose culture is consistent with their values, authenticity has become an important aspect of every company. Workers respect their managers' transparency and authenticity, so they must be expressed in the office's physical design. At the same time, businesses need to be truthful and think about how they want to promote their values in the business. When an office is established specially and authentically, workers are more innovative and inspired by the workplace.

\section{Tools in Project Management Practices}

Projects are almost always emotional endeavors for more than just a few stakeholders. It is important to integrate quality processes into any project to eliminate this emotion from decision-making and to interact more efficiently with management. Project managers must continually refine their thinking for the outcomes to be sustainable over the long run. This can be done by familiarizing with and utilizing every project's various quality tools and techniques.

1. The Seven Quality Tools

a. Stratification of data

Stratification means the act of sorting records, persons and items into separate categories or layers. This approach is used along with other methods for data analysis. When data from several sources or categories have been merged, it is difficult to see the significance of the data (What is Stratification? Stratified Analysis $\mid A S Q$, no date).

\section{b. Histogram}

Histograms are helpful when separating the frequency of your data into categories like age, weekdays, physical measurements, or any other categories that can be chronologically or numerically specified; (What Are the 7 Basic Quality Tools? | Lucid chart Blog, 2019).

c. Check Sheet (Tally Sheet)For the compilation of quantitative or qualitative data, check sheets may be used. It can be called a tally sheet when used to gather quantitative data. A check booklet collects data in the form of check or tally signs that display how many times a given value has occurred, which makes you quickly identification of defects or deficiencies, pattern errors or even causes of particular defects within your system or product. The checklists promote the registration with simple setup and accessible- to-read graphical data of preliminary frequency distribution processes.

d. Cause-and-effect diagram ("fishbone" or Ishikawa diagram)

The Diagram is used to identify all root causes behind a problem. To identify the source of variation the causes are usually grouped into major categories:

- People

- Methods

- Machines

- Material

- Measurements

- Environments 


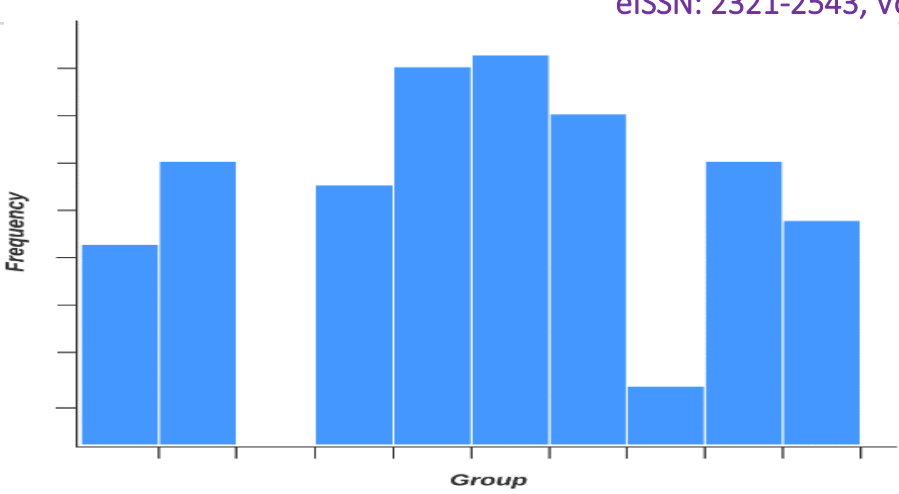

Figure 2: Histogram
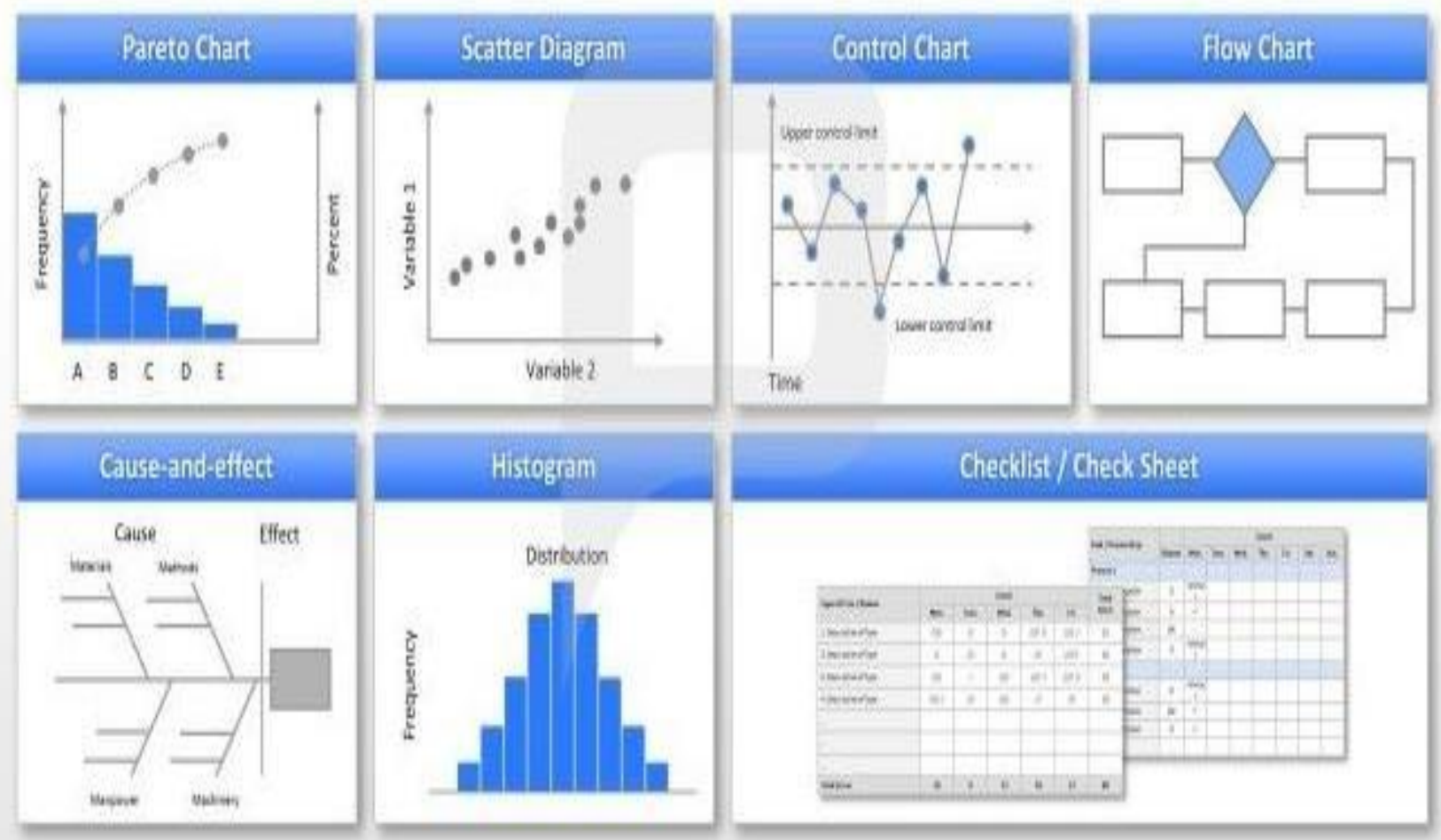

Figure 3: Check Sheet Diagram

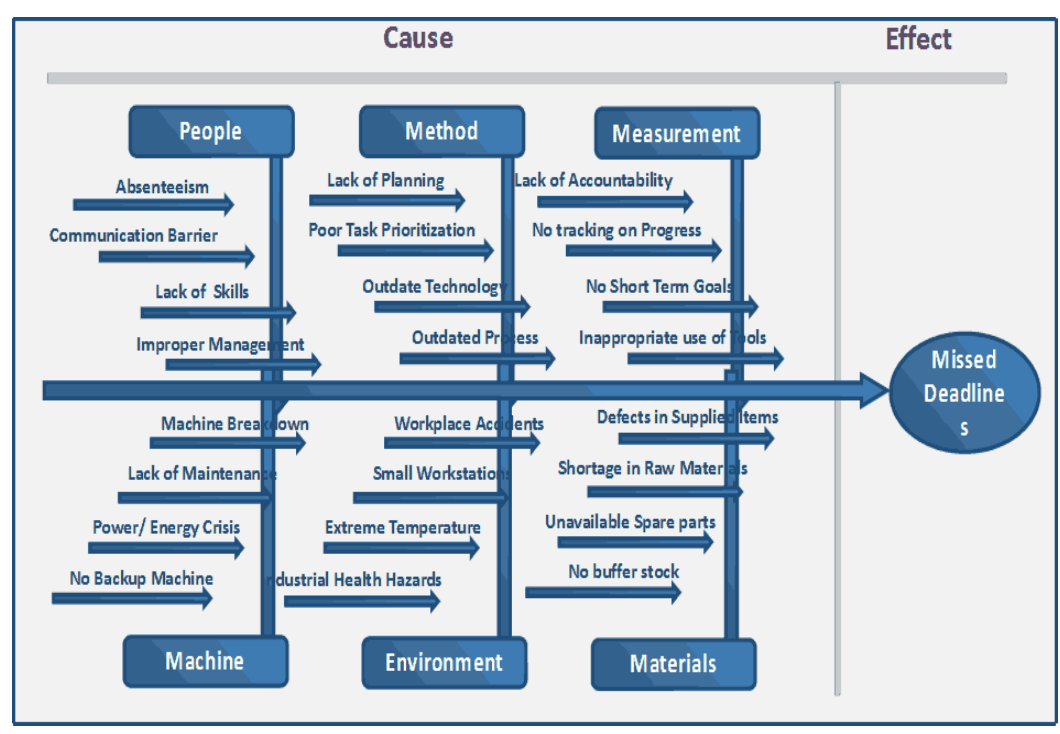

Figure 4: Cause and effect Diagram 


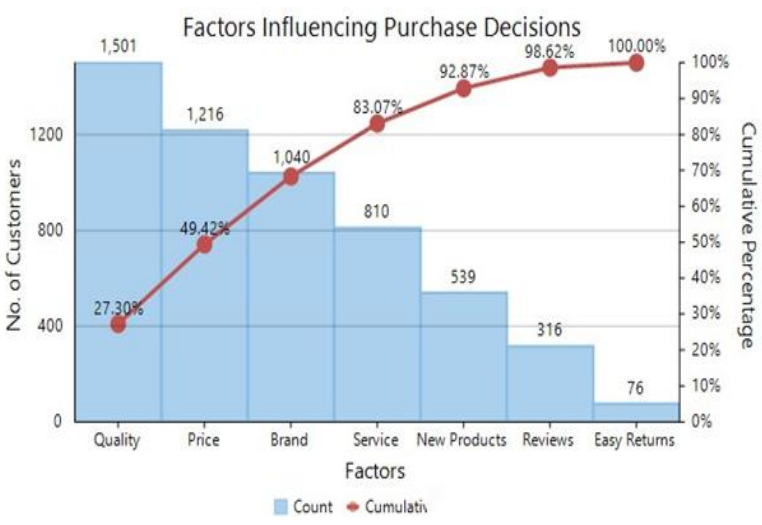

Figure 5: Factors Influencing Purchase Decisions

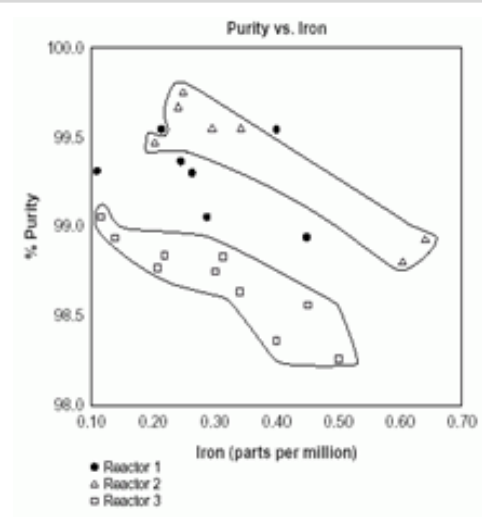

Figure 6: Scatter Diagram

It is also called a "Cause and Effect" diagram, because it lists down all the potential causes for a given effect (Ishikawa Diagram). In the industry of service, these are described as the 4S: (Cause and Effect Diagram)

- Surroundings: Is your business portraying the appropriate image? Is it dilapidated? Is it cold and impersonal? Is it a pleasant experience?

- Suppliers: Do you have any problems delivering your service? Do you have issues with meal deliveries that aren't up to par? Are there too many phone calls that go unanswered? Is your server capable of handling traffic spikes? Are you getting enough traffic through your paid advertising channels?

- Systems: Do you have policies and processes in place to deal with every eventuality? Do you have current cash registers that allow your servers to efficiently place orders and deliver checks?

- Skill: Are your staff properly educated? Do they have the necessary background?

e. Pareto Chart

Pareto chart revolves around the principle of $80-20$, which points out that in any case $80 \%$ of the problem or failure is only caused by $20 \%$ of the few major factors also called Critical Few while $80 \%$ of the remaining $20 \%$ of the problem or failure are caused by several minor factors often known as Trivial Many.

f. Scatter diagram (Shewhart Chart)

Scatter Diagram is a method for explaining changes in dependent variable due to some change to the independent variable. ('Scatter Diagram: Scatter Plot and its Development', 2014).

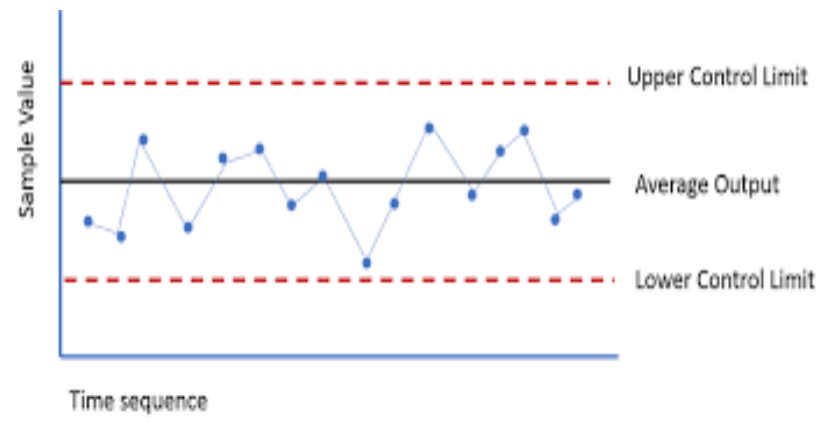

Figure 7: Control Chart

\section{g. Control chart}

Control chart is a method used to track the control or not of a procedure. It is a time graph with the middle phase and the control limits on both sides of the graph. There was a mistake (Upper Control Limit \& Lower Control Limit). The values outside the control limits display a non- controlled operation. Many other parameters detect the out-of-control essence of the mechanism.

\section{Quality Function Deployment}

QFD is a method and collection of tools to efficiently identify and turn customer requirements into precise technical specifications and plans for manufacturing goods that meet these requirements. QFD is implemented to translate customer requirements (or VOC) and move them across sub-assembly, part and manufacturing process levels down from 
the assembly level. A given collection of matrices used to make progress easier is provided in the QFD methodology. Furthermore, QFD offers a standardized system and instruments to document decisions taken and lessons learned in producing goods. This knowledge base can be used to support future ventures as a historical record.

The use of quality feature implementation has many additional advantages:

- Consumer Focused: the QFD approach stresses the needs and desires of the customer, rather than the organisation's wishes.

- Structure and documentation: QFD includes a formal method and instruments to record decisions taken during the development process and learned lessons learned during this process.

3. Process Improvement Methodologies

Process changes include the industry practice of defining, reviewing and enhancing current business processes to maximize performance, comply with principles of best practices and simply enhance consumer and end user quality and experience.

4. Theory of Constraints

Introducing the Constraint Theory (TOC), first implemented in the early 1980s by Dr. Eliyahu Goldratt, then implementing a systematic mechanism to strengthen the constraints until there has been no more limitation. According to TOC, companies often face at least one restriction, which means that anything can always be changed. Using these five repeatable steps to use TOC, to eliminate constraints:

Identify the constraint:

1. Decide how to exploit the constraint.

2. Subordinate and synchronize to the constraint.

3. Alleviate the constraint.

4. Repeat the process as needed

5. Communication management

"Communication management requires the required procedures to promote artifacts and events to achieve an efficient knowledge-sharing and to satisfy the project and its stakeholder information needs" (Project Management Institute, 2017).

There are two parts:

1. Developing an engagement plan to ensure that stakeholders are successful.

2. Activities needed for the execution of the plan for contact.

It consists of three process:

- Plan Communications Management: Establish a satisfactory method and plan for project contact focused on the information needs of each involved person or entity, the operational assets available for project use and project specifications.

- Manage Communications: ensuring that the data on the project is gathered, produced, transmitted, processed, retrieved, handled, tracked and eventually discarded.

- Monitor Communications: The project and its partner intelligence needs are being addressed.

"Early in the project life cycle, an efficient communication management plan is developed, which recognizes the diverse information needs of project players. The flow diagram below shows the communication management in the office" (Project Management Institute, 2017).

\section{Manage Communication}

Interactive communication: Two or more groups share information in real time multi directionally. It uses artifacts such as meetings, telephone calls, instant message, social media and video conferencing.

Push communication: Send or distribute the information directly to specific recipients. This means that the material is communicated without knowing that the target audience fully meets or is heard. Includes documents, memoranda, papers, emails, faxes, voice mails, blogs and news releases.

Pull communication: Use for large structured data sets, or a large audience, and allows that receivers view contents, subject to security protocols, at their discretion. These approaches include blogs, intranet pages, e-learning, libraries gained from learning and archives of information. 
"Communication handling is a mechanism to ensure that project information is gathered, produced, circulated, processed, retrieved, handled, monitored and eventually disposed of promptly. The main advantage of the process is that the information between the project team and partners will flow quickly and efficiently. This process is carried out throughout the whole project" (Project Management Institute, 2017). The communication management mechanism describes everything from identifying relevant technologies, strategies and tactics into the successful communication. In order to

meet evolving expectations of the stakeholders and the project, it should also encourage versatility in coordination practices. The following diagram explains the same.

Importance of Communication to streamline the workflow:

1. Valued in the workplace

2. In demand by businesses

3. Helps your career progression

4. Allows you to speak concisely

5. Builds better rapport with customers

6. Influences how you learn

7. Enhances your professional image

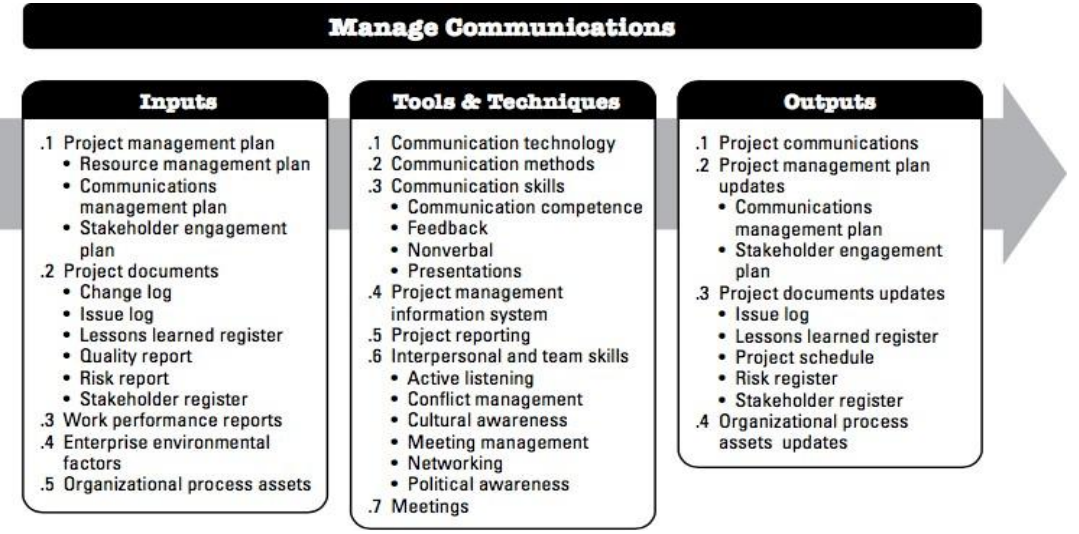

Figure 8: Manage Communication: inputs, Tools and technique, and Outputs Source PMBOK

"The most effective businesses recognize that good communication at all levels is necessary if they are to thrive in today's business environment. A handy mnemonic here to recall the advantages of good contact between you and your organization" (beqiri, 2017). "The ability to efficiently interact with consumers, colleagues and superiors is important regardless of the field in which you work. Effective communication strengthens teams, promotes high levels and improves the atmosphere of workplaces" (beqiri, 2017).

"The architecture method involves several diverse coordination mechanisms in the area of social, educational, regulatory and artistic science. There are unique signature behaviors in each of these subject areas" (Tarasova and Markova, 2018).

The social field: Public hearings and architecture proposals were debated in the social sector. This area demonstrates the general degree of contemporary society organization and the level of discourse associated with public conversation regarding the architects and custodian's plans and design decisions.

The educational field: The area of education comprises workshops, master classes, design technical courses, basic architectural and urban design research, and knowledge transfer to stakeholders. Analysis of past encounters in architecture and urban planning, its systematization, optimization of processes in contemporary design, and architectural forecasting is rational in this area.

The creative field: The area of imagination is one of the architect's principles and theories. It unites forces impacting the architecture and includes the pursuit of innovative non-conventional methods for architecture. The architect's imagination is discovering new ideas, types, shapes, building techniques and construction methods in innovation.

The regulatory field: it is a restricted field in architecture and planning, in the context of statutory and judicial actions. This sector governs building practices with the aid of codes of construction, health and welfare laws, case guidelines, legislation, decrees, civil law, economic development, the Russian Federation's housing codes and activities, such as architecture divisions, planning and land use regulations, the architectural and planning committee, the Russian Federation. 


\section{Stakeholder Management}

"Management Project Stakeholder includes the processes needed to identify individuals, groups or organizations, that could affect the project or be affected by it to assess the expectations and the impact on the project of stakeholders and to develop management strategies to involve stakeholders in project decision making effectively and project implementation"(Project Management Institute, 2017). The process includes; identification of stakeholders followed by planning of stakeholder's engagement, then managing them with lastly monitoring them.

It is a matter of nature that stakeholders are identified and engaged for the good of the project. "While Project Stakeholder Management processes are defined only once, recognition, prioritization and contribution practices should be regularly checked and revised, and at least at the times"(Project Management Institute, 2017) when the project passes through various life cycle phases; it present players participating with the project who are no longer involved or new parties are members of the project stakeholder group and when the company or the larger stakeholder group is witnessing crucial changes.

"The identification of stakeholders is the method of periodically identification, review and reporting of relevant information concerning project stakeholders, their preferences, engagement, interdependencies, control and future impacts on project performance. The main value of this process is that the project team will determine the right emphasis for each stakeholder or community of stakeholders" (Project Management Institute, 2017).

Project Stakcholder
Management Overview
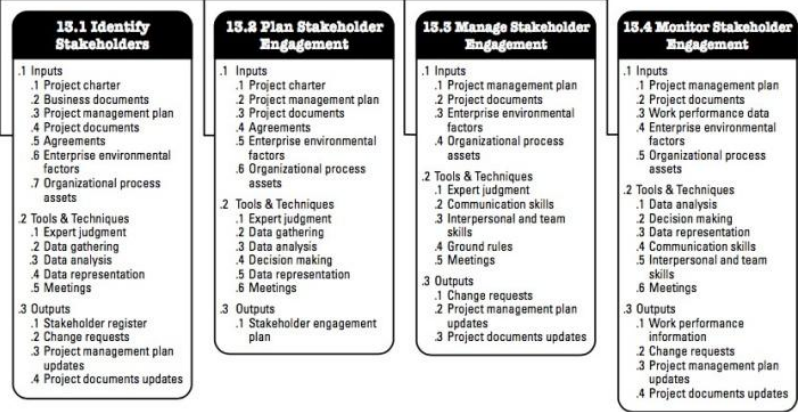

Figure 9: Project Stakeholder Management Overview, Source - PMBOK

"The consequence of these mechanisms is a four-tier hierarchy, which defines how stakeholders are managed: The following:

1. Inform: The stakeholders that need minimum effort are in this group. Less-powered, yet more legitimate stakeholders must be aware of decisions which could directly impact them.

2. Consult: Some partners just need to be aware of the initiative. Since high- powered but less credible secondary stakeholders need to be consulted to gain views and insight on important decisions that impact them directly or indirectly.

3. Involve: Stakeholders with high levels of authority, and those with low credibility, must engage in all project activities according to their interest, since they have the power to vote on the project.

4. Partner/ Collaboration: Primary stakeholders have the authority and leverage to impact the progress of the initiative. Therefore, their participation and engagement can also be viewed as collaborators" (Designing buildings wiki, 2020).

\section{DOCUMENTATION}

"The organization is important for any business' smooth day-to-day operations. The days have gone where you tried to trace a single paper or a main file. Files must be easily stored and identified in the future in order to be productive and effective. The hunt for documents is a waste of time and money with so many tasks to complete in any given day, which could be more beneficial for other areas of your organization. It is essential to streamline document workflows and enforce a document management strategy to keep your firm productive and efficient" (Studebaker, 2019). Therefore you will take the right strategy and optimize the full potential of the document management system online in your company.

\section{Phases of a Construction Project}

To govern the project, these stages include defined decisions, deliverables, and milestone completions, ensuring that the negative impact of uncertainty is overcome at each level of the process. As a result, the project team's obligations should be specified and measured for acceptability, and liabilities should be decided objectively.

Project objectives are achieved incrementally throughout the project life cycle, based on feasibility established during the appraisal stage. The project objectives, tasks, compliance, and authorization to move to the next step should be 
broken down stage by stage through the various life cycle stages. Each stage of the construction project life cycle can be thought of as a sub-project, reducing the main project's complexity.

\section{Project Appraisal Stage}

Involves analysing the problem or need to be addressed by the project, generating solution options (alternatives) for solving the problem, selecting the most feasible option, conducting a feasibility analysis of that option, creating the solution statement, and identifying all people and organisations concerned with or affected by the project and its expected outcomes in order to approve or reject the project. Determine the viability and cost-effectiveness of a project.

Key Steps Include:

Step 1- Concept Analysis - determine the concept of the project, need for the project, cost effectiveness and feasibility, identification of stakeholders and funding request.

Step 2- Concept Brief - development of project mission, goals, objectives and vision; broad scope statement that specifies the boundaries, deliverables and requirements of the project

Step 3- Project Organisation - roles and responsibilities, team requirements and composition, implementation approach, performance measures, other info.

Step 4- Project Approval - Project Appraisal Document - summarizes all the estimations and evaluations made, to justify the project concept and verify that the proposed solution addresses the identified problem.

Pre- Construction Stage which comprises of all the main work including formalization of the design brief; Site survey and soil investigation; Hazard risk vulnerability analysis; Alternative concept designs with costing and finalisation; Preliminary designs drawings; Development of design of each discipline and their integration; Obtaining statutory approvals; Decision on construction methodology; Preliminary cost estimates; Construction working drawings and related CAD drawings; Construction working drawings Detailed cost estimate; Detailed specifications and bill of quantities; and Tender documents.

Project component sequencing: Prior to the start of the project, the building methodology must be established. The order in which project components are completed will be determined by the approach used and the resources available. This will be reviewed as the project progresses and, if required, changed.

\section{Planning tools}

Work breakdown structures (WBS): This involves the identification of total scope of work in the project, followed by dividing the project into work packages, and finally monitoring of the project performance in terms of time, cost and quality parameters.

Bar charts: This is the simplest form of project scheduling, mostly used for small and complex projects, and used in preliminary planning and tendering stage of many projects

\section{Network techniques and scheduling}

Methods of network diagramming - for complex projects, a network-based project schedule is used. The network of project activities identified by WBS is constructed using this method, which takes into account their logical linkages and interdependencies. Arrow Diagramming Method (ADM) and Precedence Diagramming Method (PDM) are two strategies for network diagramming (PDM).

\section{Network Analysis and Scheduling}

The project network, which includes activity durations and logical relationships, will be assessed using forward and backward pass schedule calculations to determine early and late start and end times of activities, as well as critical activities, critical path, and overall project length. The project schedule is made up of calendar dates for the start and end of operations, as well as the number of floats available. The network schedule must also be given in the form of a linked bar chart or a table

\section{Construction Stage}

This is one of the most important stages of construction management since it is here that pre-construction outputs are turned into concrete form while staying within budget and time restrictions. The project brief is achieved through the numerous construction project management functions specified in section 6, specifically: Time management, Cost management, and Quality management. In time management the aim is to complete the project within the stipulated period. Time management essentially involves defining project scope in the form of work breakdown structure to generate activity identification and listing, activity duration estimating, activity sequencing with interactivity dependencies, project schedule development and project schedule control. The objective of the project cost management is to ensure that the project is completed within the authorized budget. The primary processes involved in the cost management is resource planning, cost estimation, cost budgeting/cost planning and cost monitoring and control. Using the cost baseline, cost control should be done, that has periodic cost reporting, actual cost comparison with planned cost, 
early warning for corrective actions, cost control and monitoring, forecasting of final cost at completion based on cost trend and cost changes, and modification of the cost baseline for authorized cost changes and preparation of revised estimates. The Quality management in construction aims to achieve the required functional and physical characteristics of a constructed facility through planning, direction, and control. The primary goal of quality management is to achieve the quality goal of satisfying criteria by evaluating the performance of building processes and ensuring that they are directed toward overall quality, commissioning and hand over stage. After the project is complete as per specifications and designs, project commissioning and handing over stage follows. It shall need the compliance of clearing of site, removal of all defects at the time of completion and during defect liability period, preparation of list of inventories, certification and settlement of construction agency's final bills for payment, obtaining completion certificate from local government bodies/departments, preparation of maintenance manual, performance compliance verification of built facility, handing over all other required documents to the client/owner, restoration of surroundings. and preparation and handing over all as-built drawings

\section{Data Collection through Online Survey}

1) What is the type and number of employees in the firm?

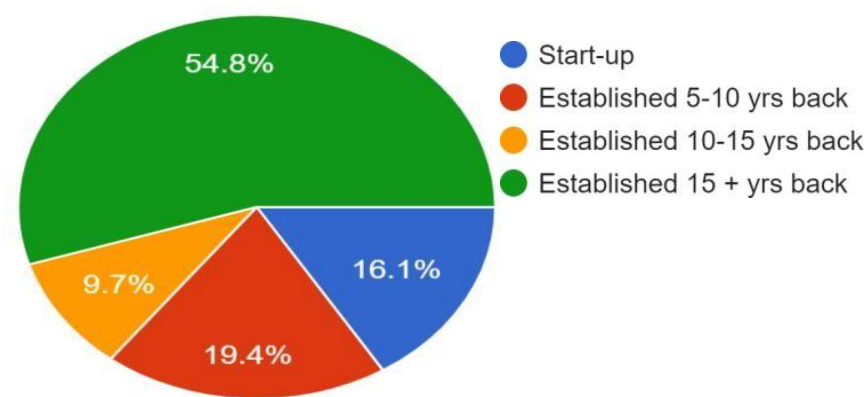

Figure 10: Type of firm

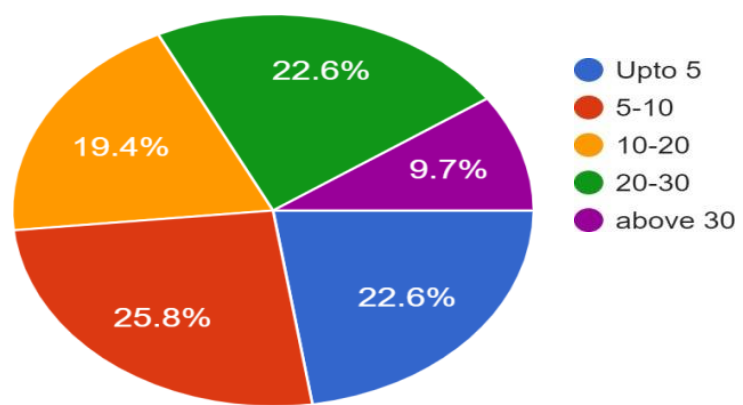

Figure 11: Size of the firm

2) Does your firm have professionals solely dedicated for the following occupations?

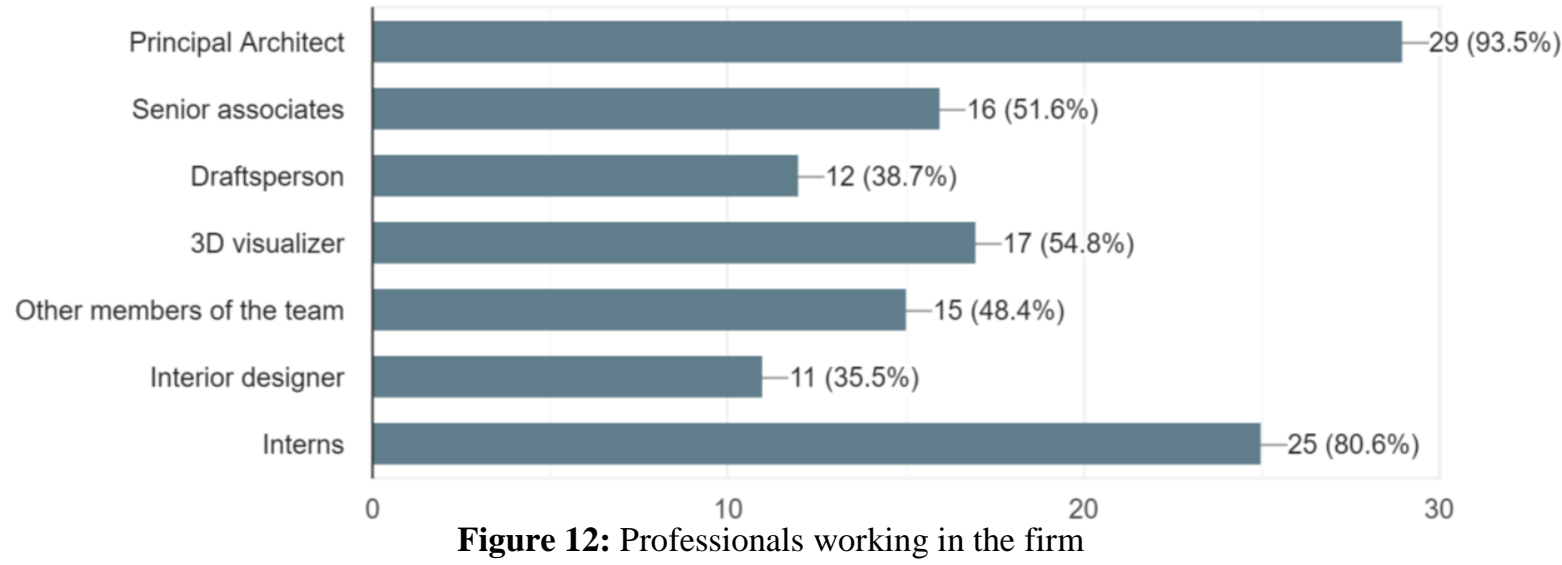

3) Who are the key decision makers in the firm?

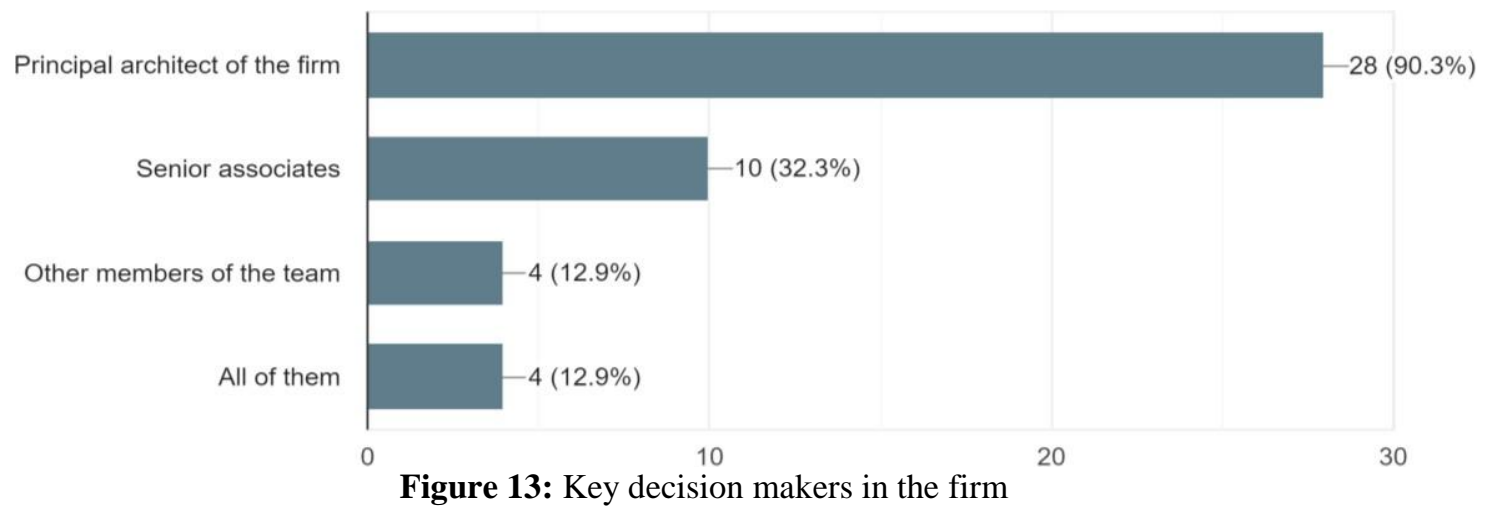

4) Steps involved in the workflow from the initial of a project till its completion? 


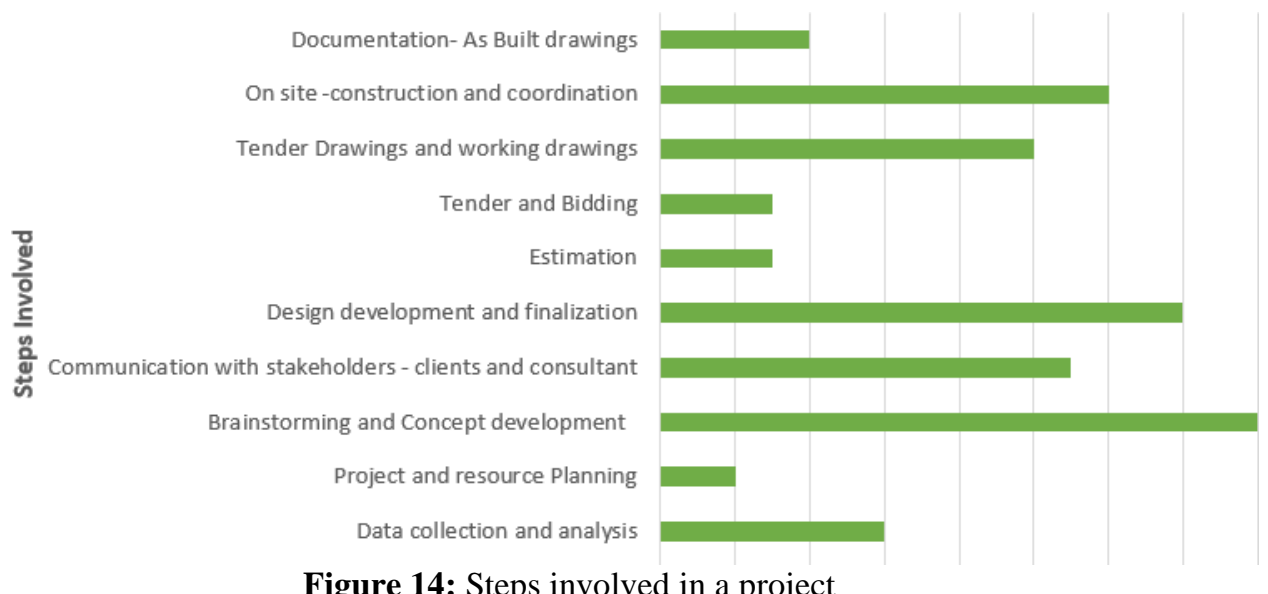

5) Problems faced by start-up firm.

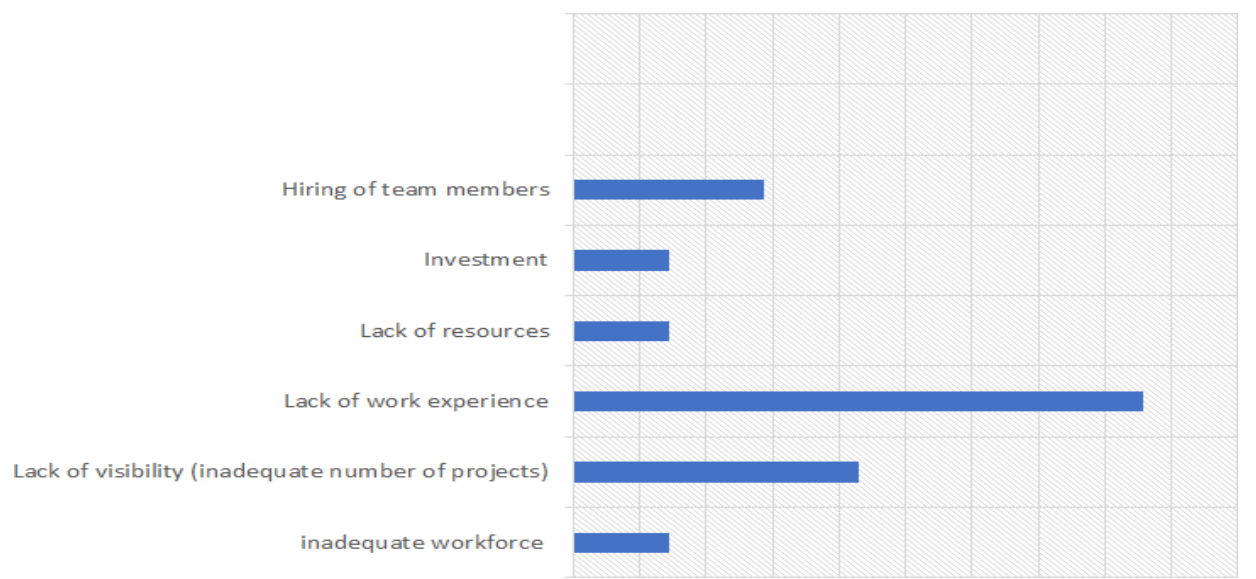

Figure 15: Problems faced by start-up firm

6) Problems faced during project lifecycle and ways to tackle those problems.

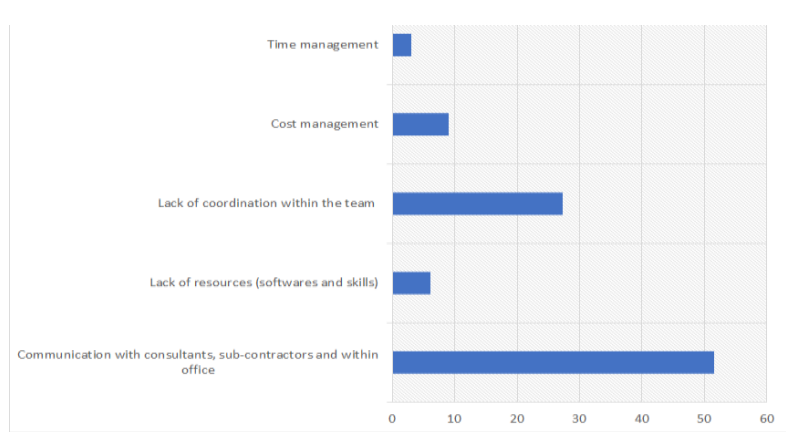

Figure 16: Problems faced during project

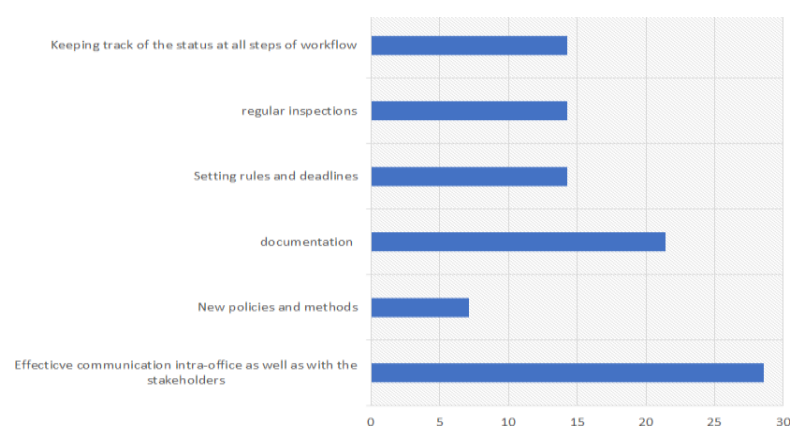

Figure 17: Tackling problems faced during project

7) Ways to tackle problems faced by start-up firms.

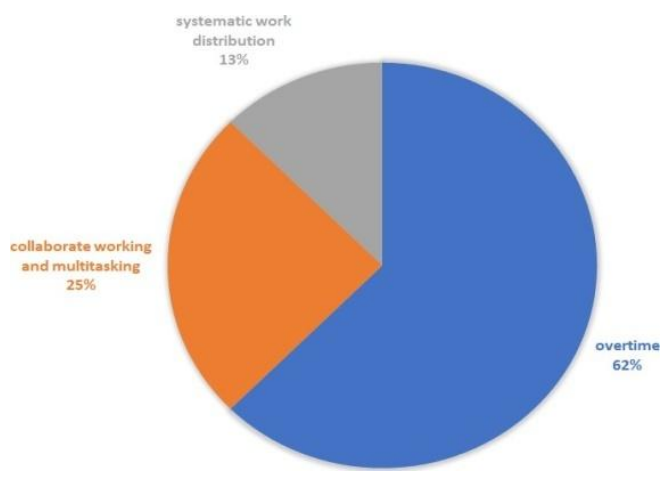

Figure 18: Start-up firm problems 
8) Were any of the tools listed below involved in Quality management/ documentation?

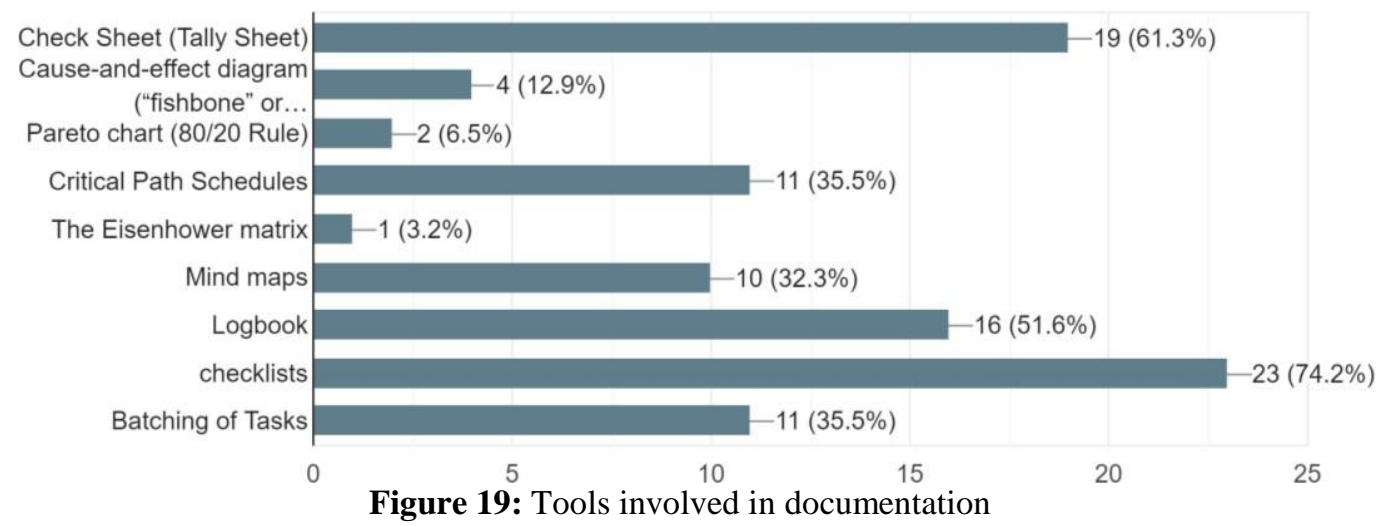

9) List the system of documentation and system of maintaining clarity in drawings.

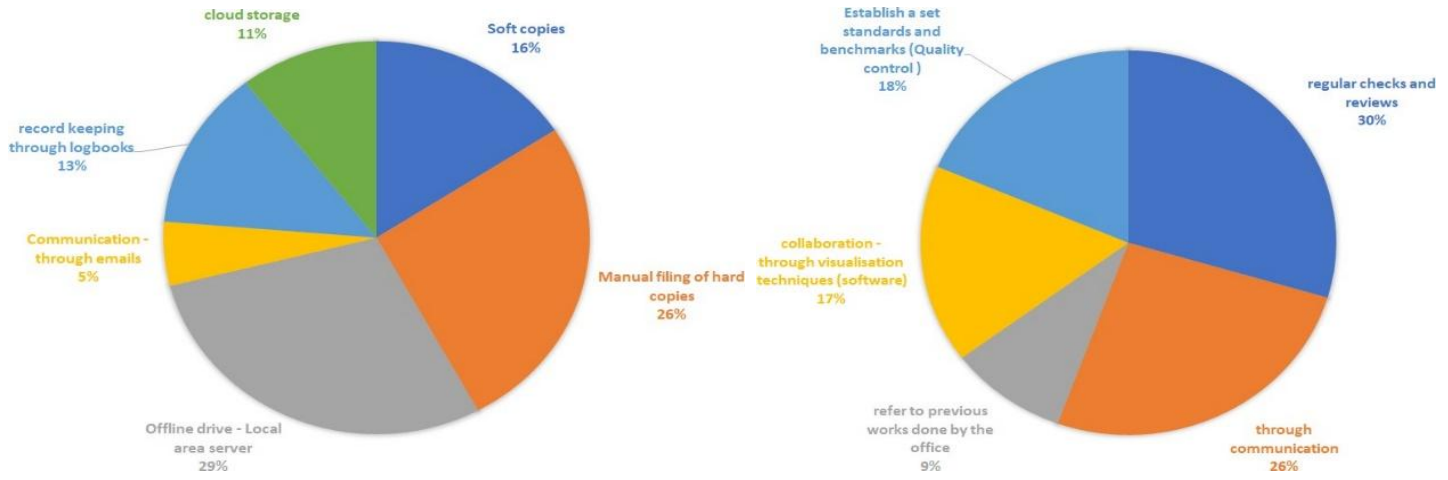

Figure 20: System of documentation

Figure 21: System of maintaining clarity in drawings

10) What are the BIM tools used by your firm?

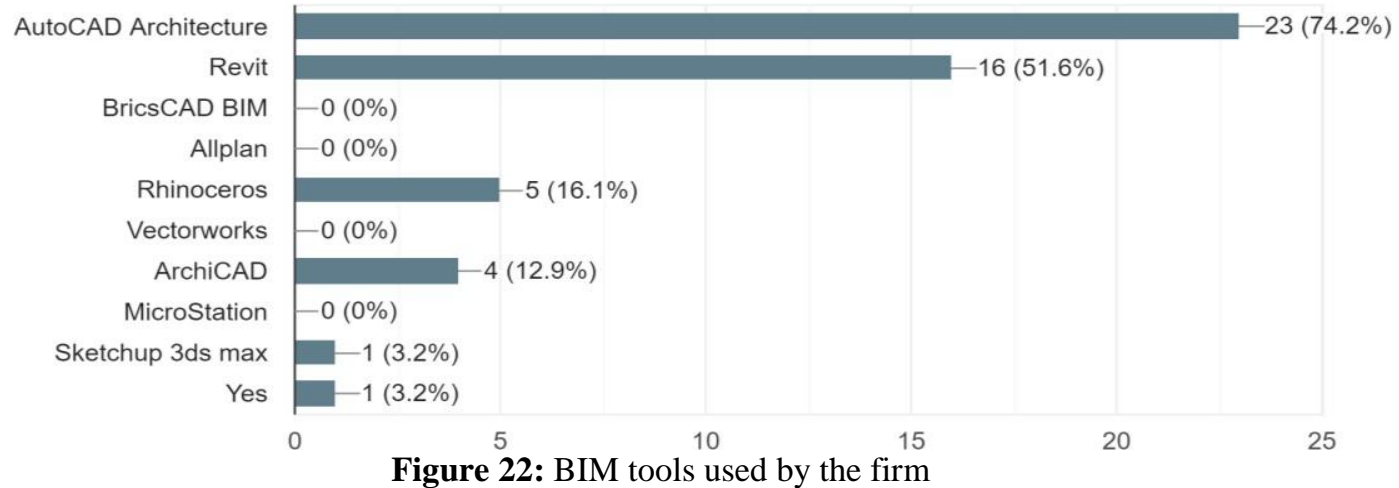

11)How is final drawing conveyed to the consultant, clients and site contactors?

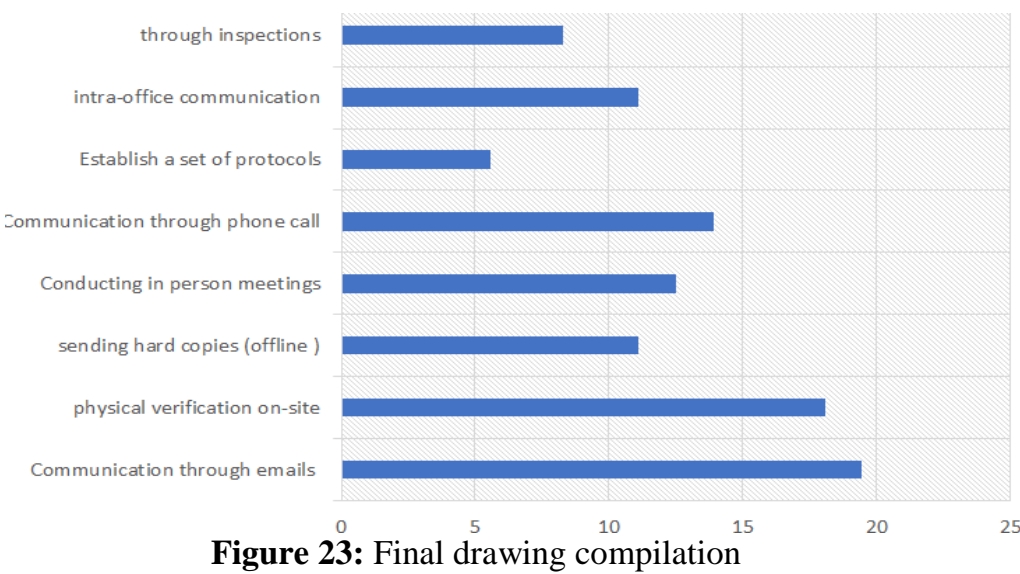


12) "The problems that arise often occur during implementation, and it seems to relate more to human factors than technological factors". Do you agree with this statement?

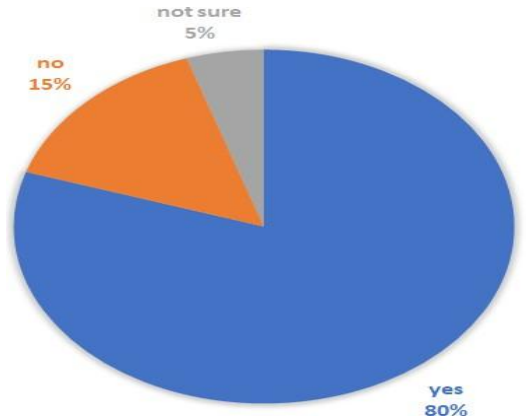

Figure 24: Cause behind the management of work

13) How will you rate each factor on its importance in having a smooth workflow in your architectural practice (starting from 1 which is Highest to lowest)?
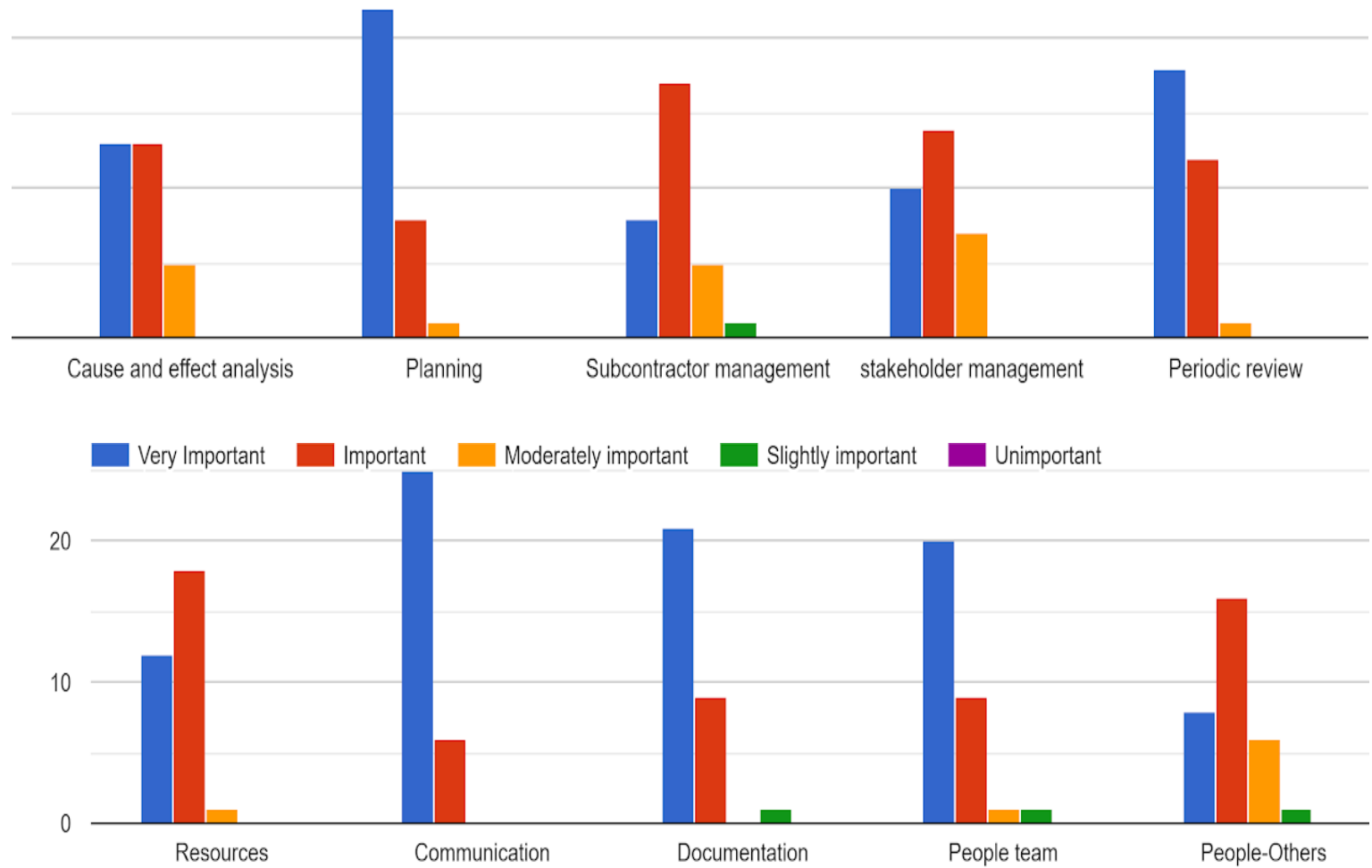

Figure 25: Factors involved having smooth workflow

\section{DATA COLLECTION THROUGH INTERVIEWS}

The collected data is formulated in Table 1.

\section{Analysis of Data}

1. The Y-axis lists out the "steps" involved in completing the project right from the initiation of a typical project in an architectural office (steps arranged in descending order from top to bottom). The X- axis depicts the frequency against the particular step. It is observed that out of the 17 responses we got, Brainstorming and Concept Development; Design Development and On site construction and coordination are the most followed steps in the industry while Project and Resource Planning; Estimation and Tender and bidding process remain the least followed.

The probable reason for this could be, some architects and architectural offices offer only designing services and do not undertake turnkey projects and do not get involved in the tendering and bidding process or the projects are small scale and forego these steps. Therefore the steps involved include only the four highest ranked in the below chart. 


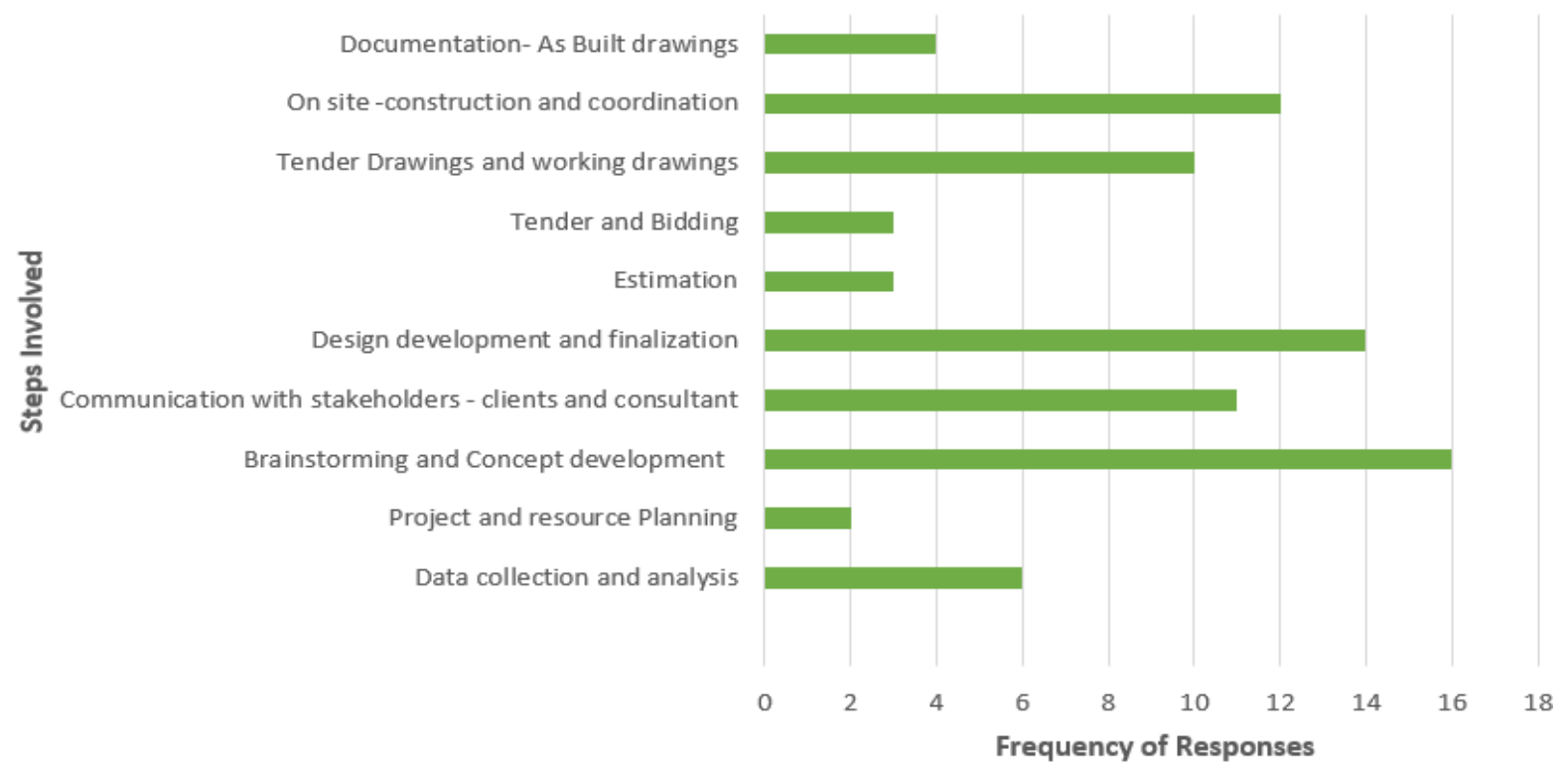

Figure 26: Steps involved in the Workflow

Table 1: Data Collection through interviews

\begin{tabular}{|c|c|c|c|c|}
\hline & $\begin{array}{c}\text { Anil Bhatia } \\
\text { (Architects Design } \\
\text { Studio) } \\
\end{array}$ & Anand Dhote & $\begin{array}{l}\text { Dimple Mittal } \\
\text { (Mayapraxis) }\end{array}$ & $\begin{array}{c}\text { Vibhor Garg } \\
\text { (Vibhor Garg \& } \\
\text { Architects) } \\
\end{array}$ \\
\hline Number of employees & $12-15$ & $8-10$ & $12-14$ & $3-4$ \\
\hline Years of experience & 35 years & 30 years & 20years & 4years \\
\hline $\begin{array}{l}\text { What are the problems } \\
\text { faced by the firm } \\
\text { during the conceptual } \\
\text { stage of a project in } \\
\text { workflow management }\end{array}$ & $\begin{array}{l}\text { Know the work output } \\
\text { and appoint } \\
\text { consultants, work in } \\
\text { collaboration }\end{array}$ & $\begin{array}{l}\text { Client's requirement and } \\
\text { understanding his vision, } \\
\text { No workflow issue at this } \\
\text { stage }\end{array}$ & $\begin{array}{c}\text { No issues in } \\
\text { workflow } \\
\text { management at this } \\
\text { stage }\end{array}$ & $\begin{array}{c}\text { Understanding } \\
\text { client's requirement } \\
\text { and working in } \\
\text { harmony }\end{array}$ \\
\hline $\begin{array}{c}\text { Strategy for } \\
\text { streamlining the } \\
\text { workflow within the } \\
\text { office with Work } \\
\text { output management } \\
\text { (interoffice) }\end{array}$ & $\begin{array}{l}\text { Management and all } \\
\text { drawings and } \\
\text { meetings are } \\
\text { organized and cross } \\
\text { checked by the firm } \\
\text { head }\end{array}$ & $\begin{array}{l}\text { Online connected server } \\
\text { with documentation, Take } \\
\text { all client requirements and } \\
\text { targets to be achieved, } \\
\text { Detailing and material is } \\
\text { decided at initial stage only }\end{array}$ & $\begin{array}{l}\text { Style of working } \\
\text { with well- defined } \\
\text { style of format to be } \\
\text { followed with list of } \\
\text { reference drawings }\end{array}$ & $\begin{array}{l}\text { Proper management } \\
\text { and writing goals to } \\
\text { be achieved at start } \\
\text { of every week }\end{array}$ \\
\hline $\begin{array}{r}\text { What is th } \\
\text { main } \\
\text { docum }\end{array}$ & $\begin{array}{c}\text { Documentation- } \\
\text { Transmitter, Mail and }\end{array}$ & $\begin{array}{r}\text { Docume } \\
\text { Bot }\end{array}$ & $\begin{array}{r}\text { Online } \\
\text { recor } \\
\mathrm{m}\end{array}$ & $\begin{array}{r}\mathrm{M} \\
\mathrm{dec} \\
\mathrm{doc}\end{array}$ \\
\hline $\begin{array}{c}\text { and mode of } \\
\text { communication in your } \\
\text { firm }\end{array}$ & $\begin{array}{c}\text { maintaining MOM } \\
\text { (minutes of meetings) }\end{array}$ & $\begin{array}{r}\text { Online } \\
\text { communice } \\
\text { what's }\end{array}$ & $\begin{array}{r}\text { and } \mathrm{r} \\
\mathrm{me}\end{array}$ & \\
\hline $\begin{array}{l}\text { How is the workflow } \\
\text { managed with } \\
\text { consultants } \\
\text { (intraoffice)? }\end{array}$ & $\begin{array}{l}\text { Mail system and all } \\
\text { drawings go through } \\
\text { the firm and not } \\
\text { directly by the } \\
\text { consultants to the site }\end{array}$ & $\begin{array}{r}\text { Consultant } \\
\text { direc }\end{array}$ & $\begin{array}{l}\text { Regular updates and } \\
\text { exchange of } \\
\text { drawings at each } \\
\text { stage and work in } \\
\text { collaboration }\end{array}$ & $\begin{array}{l}\text { Get survey properly } \\
\text { to reduce issues and } \\
\text { conflicts at later } \\
\text { stage }\end{array}$ \\
\hline $\begin{array}{c}\text { Strategy for } \\
\text { streamlining the } \\
\text { workflow with the } \\
\text { consultants }\end{array}$ & $\begin{array}{l}\text { Proper coordination } \\
\text { and records }\end{array}$ & $\begin{array}{l}\text { Make the complete set of } \\
\text { drawings together before } \\
\text { construction }\end{array}$ & $\begin{array}{l}\text { Regul } \\
\text { and ir } \\
\text { from }\end{array}$ & $\begin{array}{r}\text { Cor } \\
\text { draw } \\
\text { con }\end{array}$ \\
\hline $\begin{array}{l}\text { Changes and revisions } \\
\text { are also not } \\
\text { appropriately managed } \\
\text { and often wrong } \\
\text { versions of drawings } \\
\text { are released? } \\
\end{array}$ & $\begin{array}{l}\text { It has never happened } \\
\text { if proper management } \\
\text { is followed }\end{array}$ & $\begin{array}{l}\text { Issues are resolved by firm } \\
\text { only, Revision drawings } \\
\text { and updates. }\end{array}$ & $\begin{array}{l}\text { A well-defined } \\
\text { network is formed } \\
\text { to avoid conflicts }\end{array}$ & $\begin{array}{c}\text { Cross check all } \\
\text { drawings by head of } \\
\text { the firm }\end{array}$ \\
\hline $\begin{array}{l}\text { Resolve conflicts at } \\
\text { site and drawings? }\end{array}$ & $\begin{array}{c}\text { Happens with lack of } \\
\text { management and }\end{array}$ & $\begin{array}{l}50 \% \text { work is done before } \\
\text { construction starts, Firm }\end{array}$ & $\begin{array}{l}\text { Management with } \\
\text { site supervision }\end{array}$ & $\begin{array}{l}\text { Dealing with } \\
\text { contractors and }\end{array}$ \\
\hline
\end{tabular}




\begin{tabular}{ccccc}
\hline & $\begin{array}{c}\text { supervision by senior } \\
\text { person }\end{array}$ & has to do the supervision & management \\
\hline $\begin{array}{c}\text { What are the BIM } \\
\begin{array}{c}\text { softwares used by your } \\
\text { firm to streamline the } \\
\text { workflow? }\end{array}\end{array}$ & $\begin{array}{c}\text { No BIM } \\
\text { software used by the } \\
\text { firm }\end{array}$ & $\begin{array}{c}\text { No BIM } \\
\text { software used by the firm }\end{array}$ & $\begin{array}{c}\text { Yes, Revit as BIM } \\
\text { software used by } \\
\text { the firm in some } \\
\text { projects }\end{array}$ & $\begin{array}{c}\text { Yes, Ecotech used } \\
\text { sometimes }\end{array}$ \\
\hline $\begin{array}{c}\text { What were the } \\
\text { problems faced by } \\
\text { your firm during the } \\
\text { initial setting- up } \\
\text { process with workflow } \\
\text { management? }\end{array}$ & $\begin{array}{c}\text { Experience is the key } \\
\text { to solve all problems }\end{array}$ & $\begin{array}{c}\text { Difficulty in getting } \\
\text { constant work and } \\
\text { resources }\end{array}$ & $\begin{array}{c}\text { Handling people } \\
\text { and resources }\end{array}$ & $\begin{array}{c}\text { Experience in job } \\
\text { helps to reduce } \\
\text { problems in the } \\
\text { setting up of firm, } \\
\text { manage resources }\end{array}$ \\
\hline
\end{tabular}

2. The figure below shows the 80-20 Pareto Chart for the problems faced during an architectural project's lifecycle as reported in the online survey. The findings indicate that the two significant problems are Communication with consultants and subcontractors and Lack of coordination within the office. The two problems consist of what Pareto defines as the "Vital Few". The line graph depicts the cumulative percentage share of each problem. If we eliminate the first two problems, the line graph corresponds to $81 \%$ meaning if we eliminate these two, the $81 \%$ of the bottlenecks in the workflow will be removed.

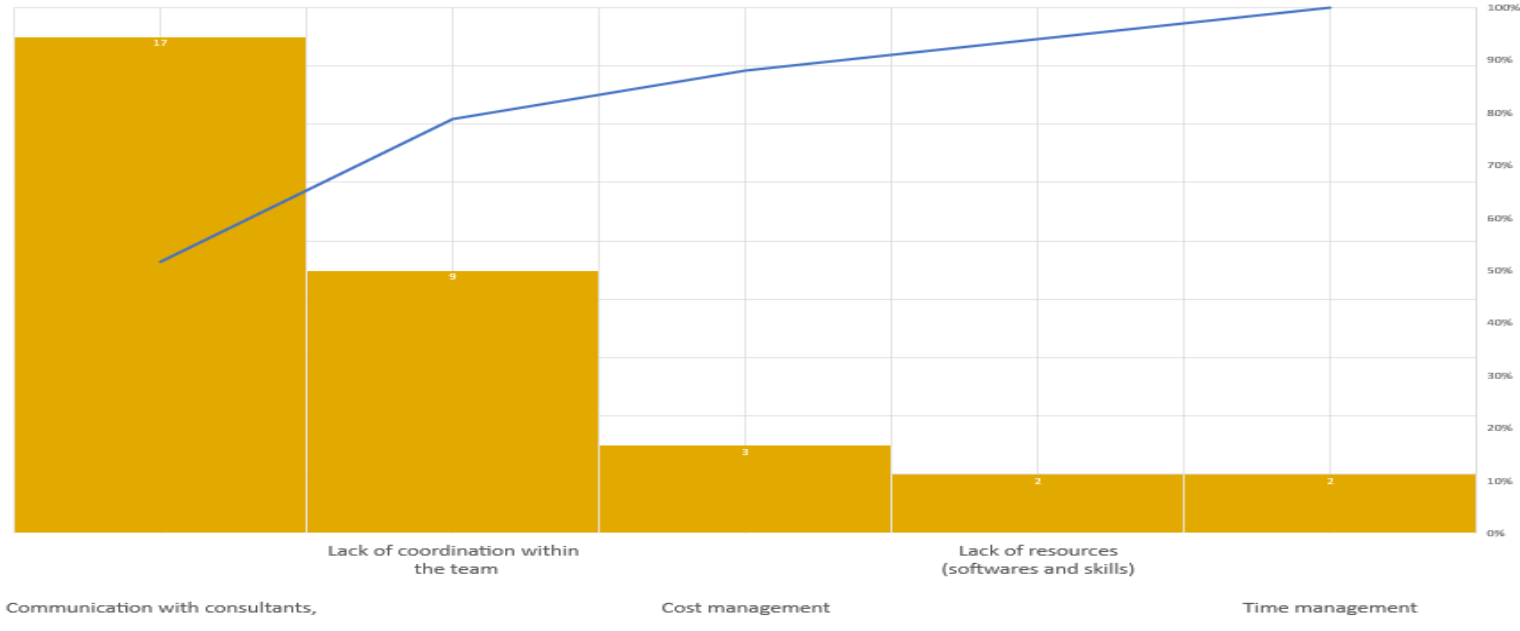

sub-contractors and within office

Figure 27: Problems faced during project lifecycle

The figure below shows the 80-20 Pareto Chart for the problems faced by firms during the initial setting up as reported in the online survey. As clear from the findings, the three major problems are Lack of work experience; Lack of visibility and inadequate number of projects, and hiring team members. The three problems consist of what Pareto defines as the "Vital Few". The line graph depicts the cumulative percentage share of each problem. If we eliminate these first three problems, the line graph corresponds to $80 \%$ meaning if we eliminate these two, the $80 \%$ of the bottlenecks faced during the initial setting up of the firm could be eliminated.

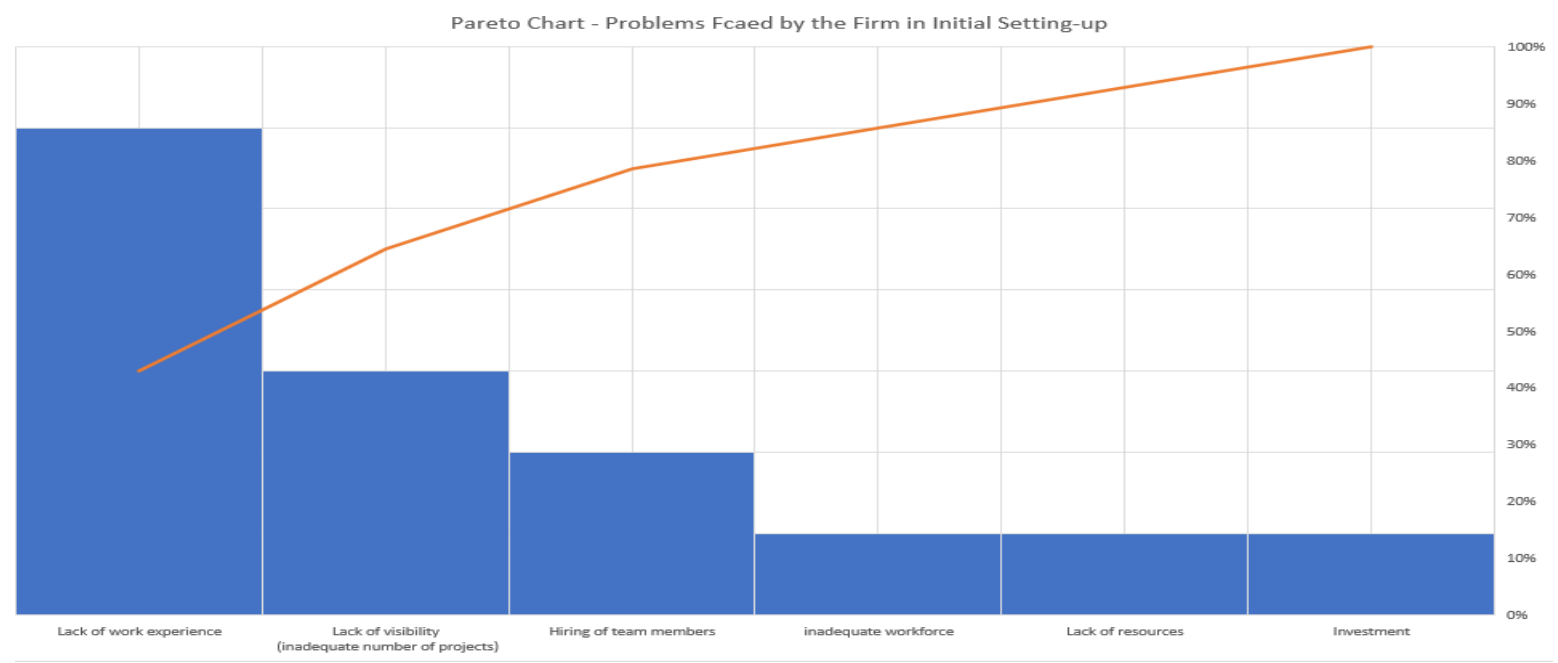

Figure 28: Problems faced during initial setup 
Table 2: Problems identified

\begin{tabular}{|c|c|}
\hline 1. Problems faced during a project's life & Communication with consultants and subcontractors \\
\hline cycle & Lack of coordination within the office \\
\hline 2. Problems faced during starting up of a & Lack of work experience \\
\hline & $\overline{\text { Lack of visibility and inadequate number of projects. }}$ \\
\hline & Hiring of Team members \\
\hline
\end{tabular}

Hence, the following "vital few" problems are investigated with the help of Cause and Effect diagram using the principle of the 5 Whys in which five continuous whys are asked to get to the root cause of the problem.

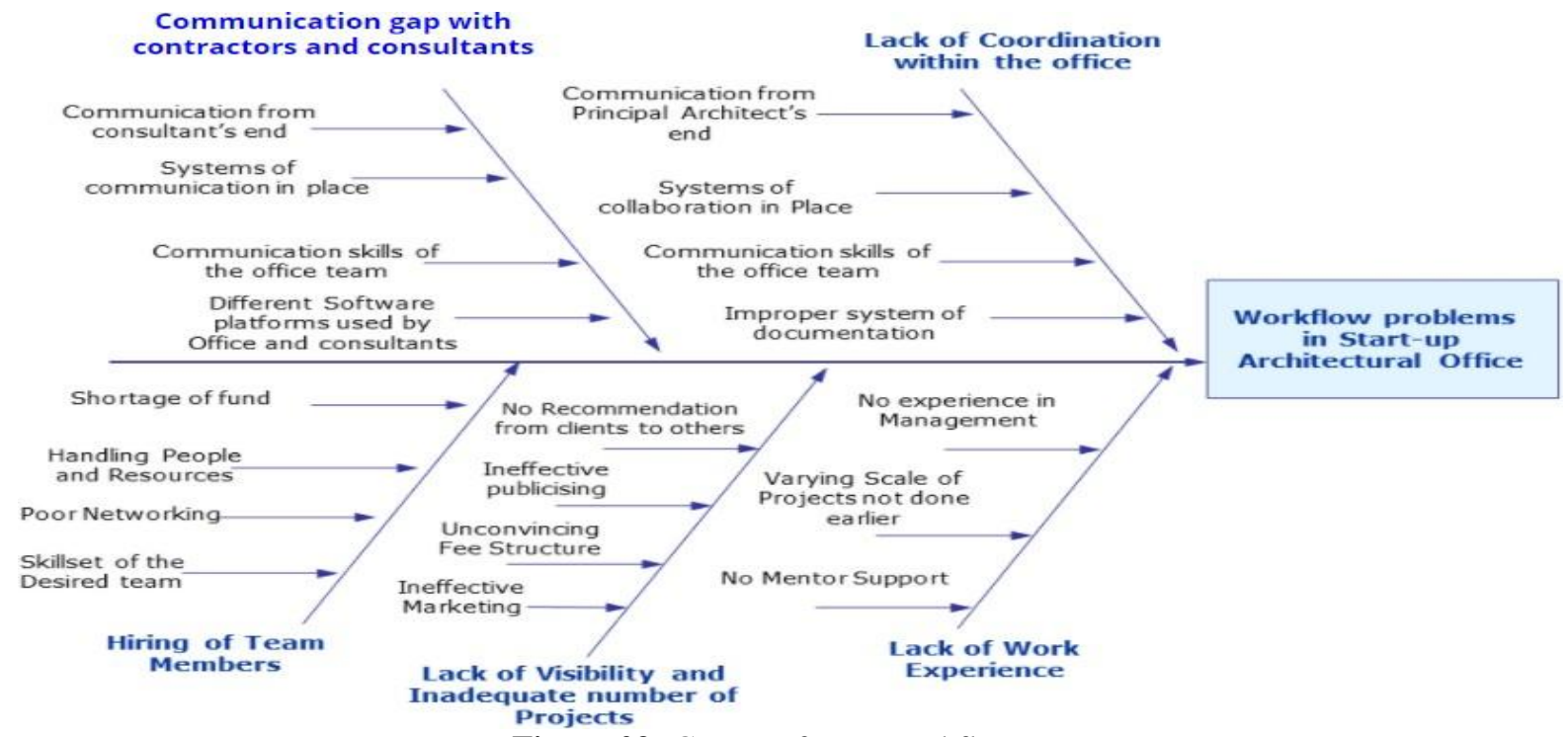

Figure 29: Causes of poor workflow

\section{Data Collection through Interviews- Stage 2}

\section{Project Appraisal Stage}

1. Project appraisal involves inception, feasibility, cost benefit analysis and strategic planning. How often your firm was involved in the project at this stage?

Depends on the scale of the project, better that the firm is involved from the initial stage

2. What are the problems faced by your firm during this stage :

a. In documentation- no difficulty

b. In communication Inter office - no difficulty

c. In communication Intra office - no difficulty, maybe occur sometimes

3. Conception and development of project brief is a part of this stage, what are the problems faced in translating the client demands into a brief and subsequently into a concept?

\section{Client satisfaction and lack of clarity from client's demand}

4. Cost benefit analysis for the project as well the definition of its budget is also done at this stage, Do you think any cost overruns are caused because of a faulty appraisal or do these overruns occur because of faults at other stages ?

\section{Cost Analysis plays a crucial role and deciding factor from this very first stage.}

5. Technical appraisal of the project determines the feasibility of the availability of the raw materials, equipment, skilled man power. Are cost overruns caused by both the cost and requirement of the mentioned things change till the completion of the project?

\section{This may happen because of availability, change in requirements and client's demand at later stage}

6. Technical appraisal of the project determines the feasibility of the availability of the raw materials, equipment, skilled man power. Are cost overruns caused by both the cost and requirement of the mentioned things change till the completion of the project?

Depends on the scale of the project, but yes cost overruns usually happens because of change in requirement of the raw material, equipment, man power or some other changes in client's demand at a later stage 


\section{Pre- Construction Stage}

1. Project development is the first step of the pre-construction stage. Is your firm usually involved in the project appraisal stage?

Yes, involvement of firm is important for better execution of the project from the initial stage only, along with collaboration of other consultants

2. Usually, how many teams are involved while detailing the methodology of construction? What is the frequency of revisions? Is everyone involved in the review process or only the teams directly involved in the construction stage?

Separate teams are dedicated for construction stage with architects and on site engineers with regular revisions to maintain and overlook the ongoing construction. The team involved in construction stage is responsible for the review process.

3. Typically, both the architectural and engineering teams work together, with the owner, to create a design. How do you ensure that information is flowing freely between the design and engineering teams?

Continuous exchange of updates via mail, server to ensure smooth execution of work and updates in harmony between the architectural and engineering teams.

\section{Construction Stage}

1. What are the causes of delay in project in construction stage?

Changes at later stage, delay in drawings, wrong implementation of drawings, labour, funding

2. What are the biggest obstacles you have encountered during a project. What steps did you take to resolve them and how is two different projects can be handled simultaneously?

The key is management within the team and all consultants and satisfying the client's requirements.

Focus on quality with proper time management

3. How do you structure a team for a construction project?

Combination of architects and engineers with all management and decision-making power to get work done on site during the construction stage. Also, accounting labour and material accountability

4. Commission and hand over stage

1. How can we get construction project handover procedure right, what are the risks involved?

Bills, built drawings, inventory

2. What kind of data should be compliance after the project is complete as per specifications and designs?

Final bills, performance compliance, maintenance

Analysis

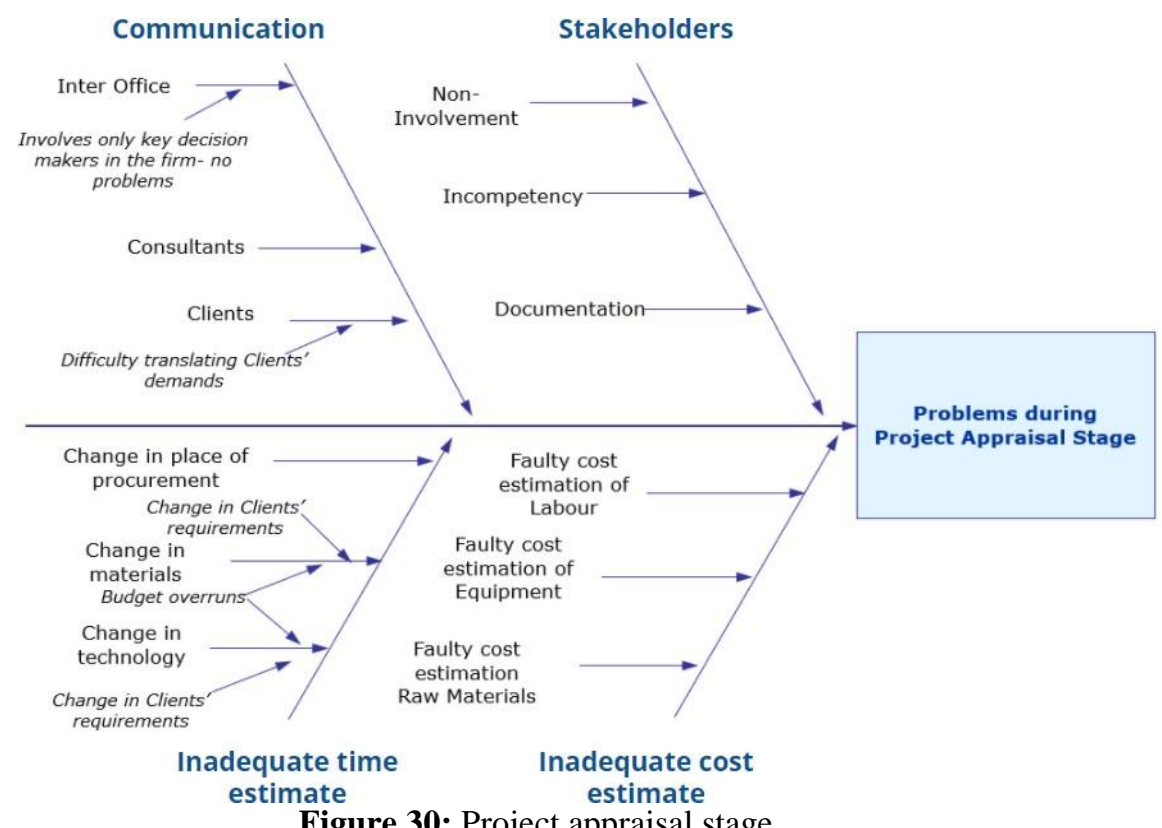




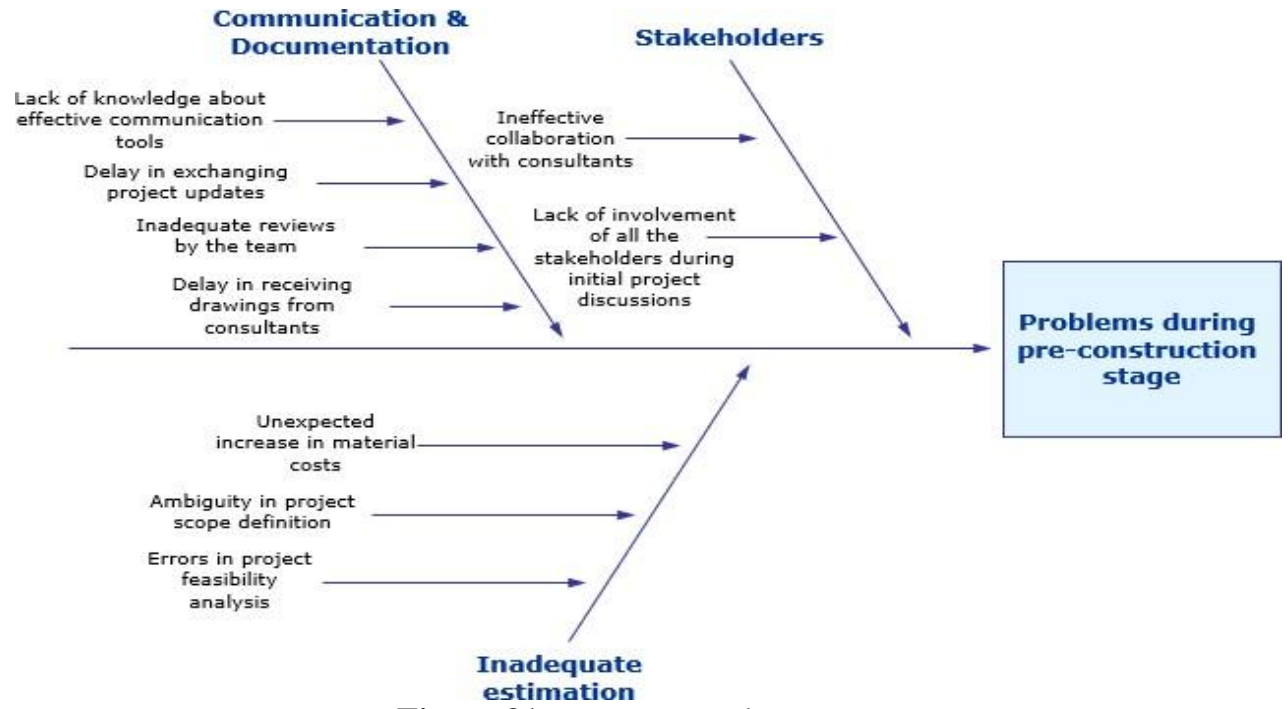

Figure 31: Pre-construction stage

\section{COMMUNICATION}

STAKEHOLDERS

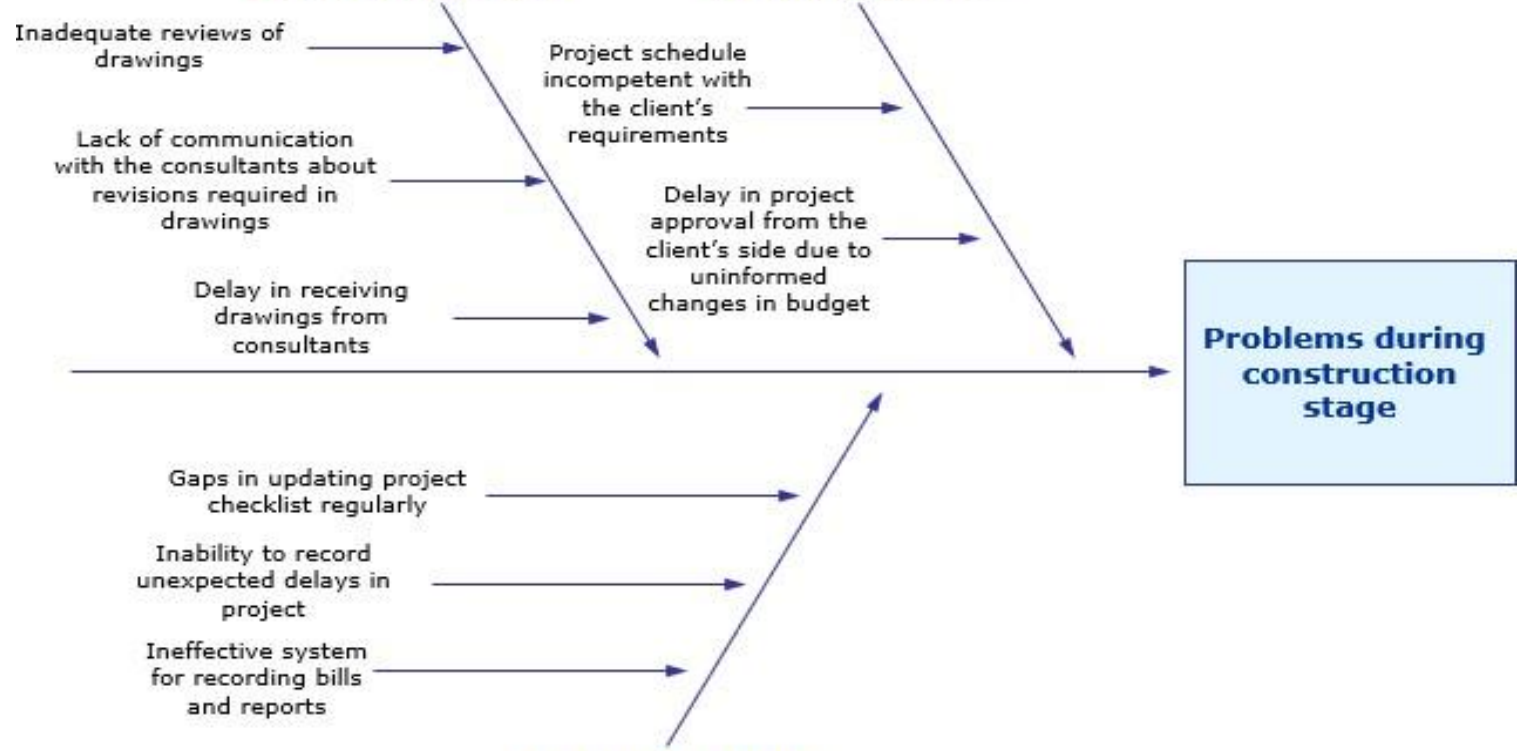

DOCUMENTATION

Figure 32: Construction stage

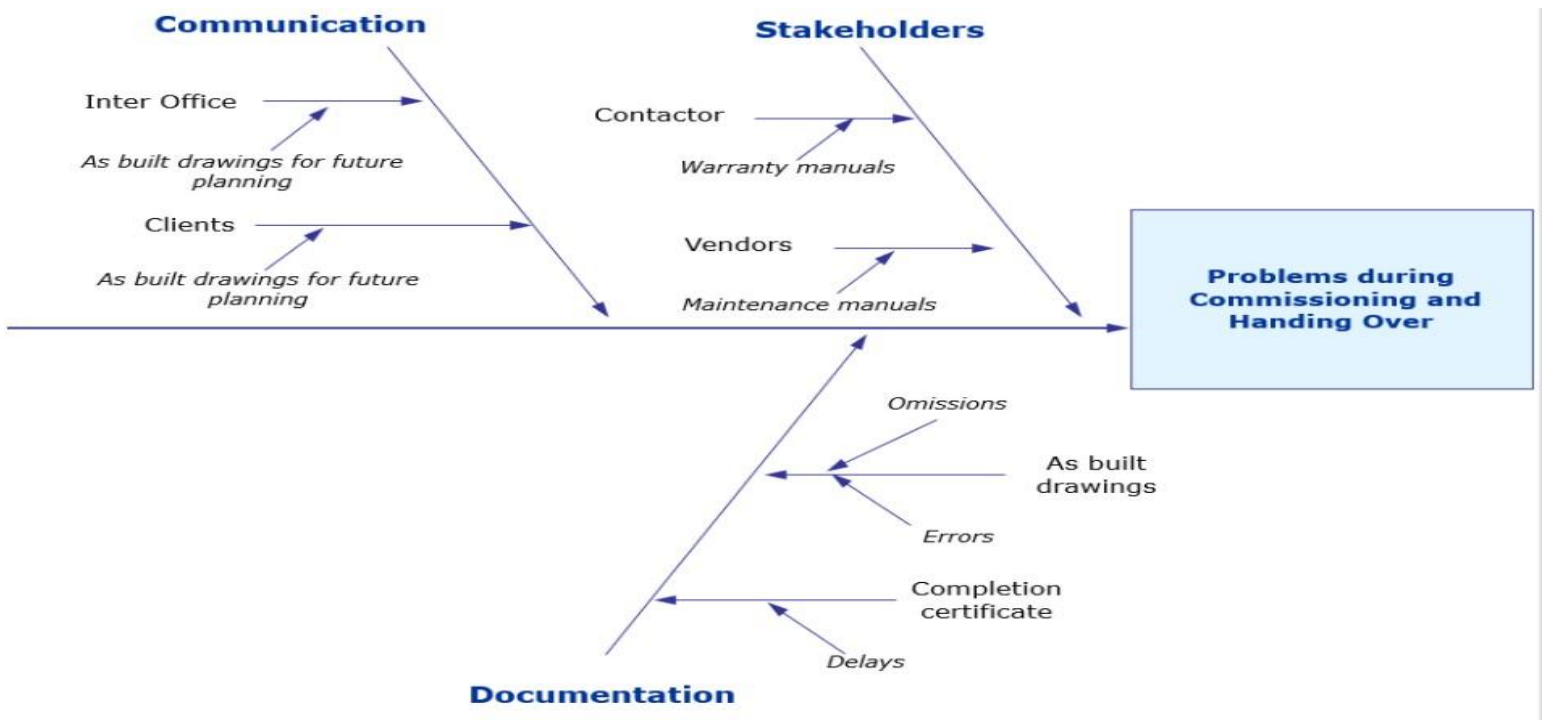

Figure 33: Commissioning and handing-over stage 


\section{Inferences}

After data collection and analysis from online survey and interviews, a list of inferences has been drawn that can be beneficial for effective and efficient workflow management for a startup architectural firm to reduce conflicts at the site and increase work output. Below is a compilation of these inferences that may act as a list of recommendations. This has been done as per the sequence of the design process involved in a project which starts with conceptual stage, interoffice management, managing the consultants followed by on site management and execution of the project.

WORKFLOW MANAGEMENT

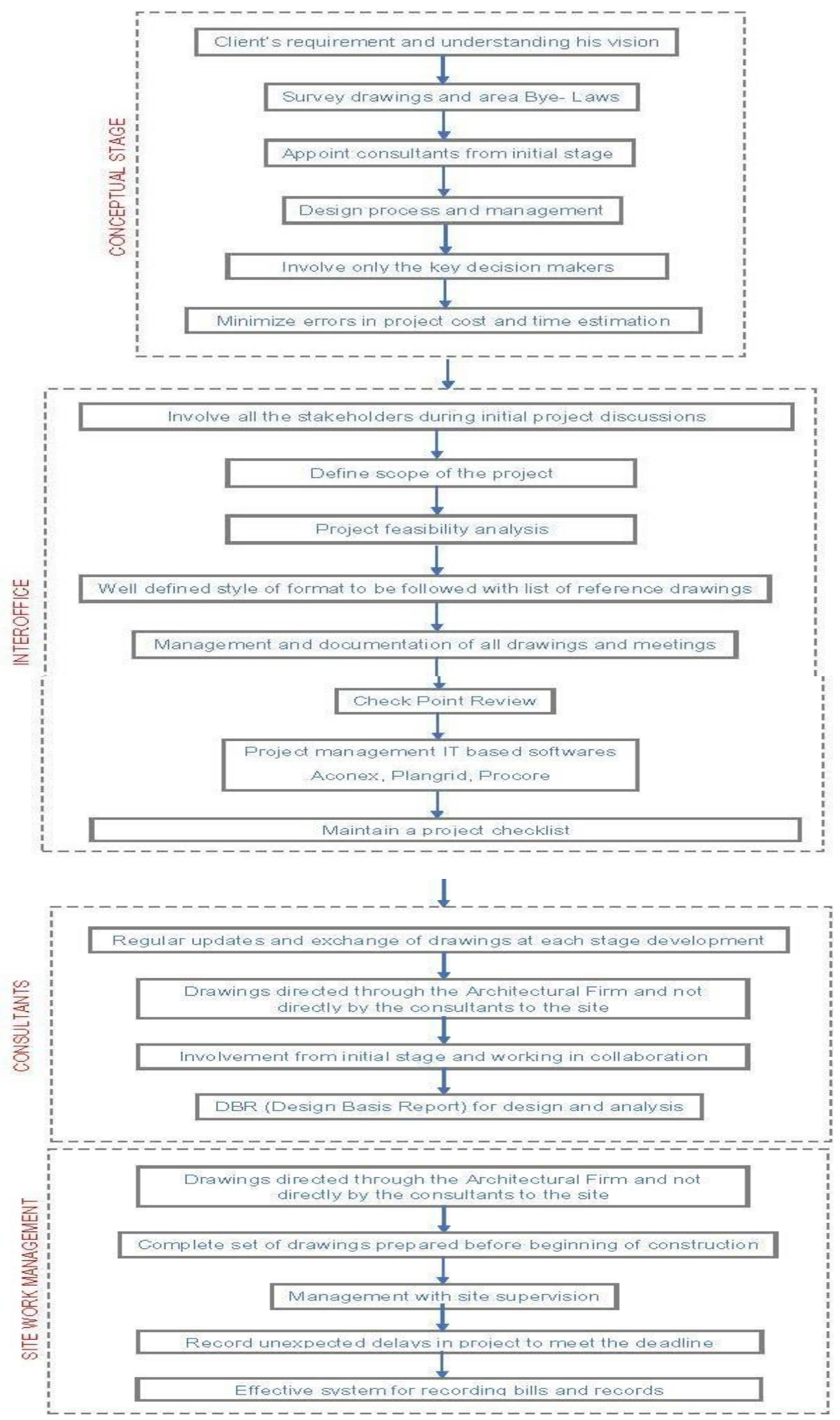

Figure 34: Workflow management 


\section{CONCLUSION}

The workflow in a startup architectural startup practice is the critical element to ensuring efficient and effective work output.

It is essential to maintain a balance and manage all the stages of the design process from conceptual stage to the final executive of the project. The seven quality tools, communication and documentation can be helpful to increase work efficiency. The major problems and challenges to be kept in mind are communication with consultants, subcontractors and coordination within the office to ensure a mistake free work environment. For a startup firm work experience, visibility and adequate number of projects with management of people and resources are the most important factors that influence the establishment of a firm.

Each stage of design process involves various challenges and requires planning to ensure a smooth transition with maximized work output. The workflow management at the conceptual stage can be monitored by proper survey drawings, understanding of building bye-laws, and understanding the client's requirement. Use of IT based platforms like aconex, plangrid, procore, projectmates can be beneficial to compile all documents, drawings with ease to share between people, organizations, comments, stage development documentation and access for improved office workflow management. To ensure no conflicts arise at the site, all drawings should be directed through the firm and not directly by the consultants, followed by regular meetings and updates with the consultants. A DBR (design basis report) can be used between firm and consultant to compile data required for analysis, design and detailing of a structure. It is intended to develop a scheme showcasing the proposed structure can satisfy architectural, service and structural requirements. The most important aspect that affects workflow is proper communication, documentation and management of people, and resources for an efficient work output.

\section{ACKNOWLEDGEMENTS}

This research paper being written as a part of academic exercise of Professional Practice course of X semester of B.Arch. calls for giving due acknowledgement to our exemplary course faculty Ar. Varun Seth for his valuable inputs and their outstanding guidance through.

\section{REFERENCES}

1. 'QFD $\mid$ Quality Function Deployment $\mid$ Quality-One' (2017).

2. Ahire, S.L., Goldhar, D.Y. and Waller, M.A. (1996). Development and validation of TQM implementation constructs'. Decision Sciences, 27(2), 23-57.

3. Anderson, R.D., Jerman, R.E. and Crum, M.R. (1998). Quality management influences onlogistics performance'. Transportation Research-E, 34(2), 137-48.

4. Beqiri, G. (2017). Importance of Communication Skills in Business.

5. Cause and effect Diagram, (no date), https://www.smartdraw.com/cause-and-effect/

6. Designing buildings wiki (2020). Stakeholder management for building design and construction. https://www.designingbuildings.co.uk.

7. Flynn, B.B., Schroeder, R.G. and Sakadibara, S. (1994). A framework for quality management research and an associated instrument. Journal of Operations Management, 11(4), 339-66.

8. Parkes, A. (2004). A Case Study of Workflow Implementation Success Factors.

9. Project Management Institute (2017). A Guide to the Project management body of knowledge / pmbok Guide Sixth Edition - PDF Drive.

10. Project Management Institute (ed.) (2017) A guide to the project management body of knowledge/Project Management Institute. Sixth edition. Newtown Square, PA: Project Management Institute (PMBOK guide).

11. Saraph, J.V., Benson, P.G. and Schroeder, R.G. (1989). An instrument for measuring the critical factors of quality management. Decision Sciences, 20(4), 810-829.

12. Studebaker, K. (2019). Benefits of streamlining document workflows and document management.

13. Tarasova, I. and Markova, Y. (2018). Communication in architectural practice and theory with reference to the city of Ekaterinburg. IOP Conference Series: Materials Science and Engineering, 451, 012174.

\section{Appendix Questionnaire/survey}

Structure of the firm:

1. Size of the firm

2. Hierarchy

System of work-flow management

1. Steps involved in the workflow from the initiation of a project till its completion

2. Problems faced by the firm during the project lifecycle 
- Within the office

- With Consultants

- At the site

3. How does your firm maintain the quality of drawings to meet a specific benchmark?

4. What is the system of maintaining documentation in your firm?

5. How do you convey the new changes to your consultants, clients and on site con

6. Were any of the tools listed below involved in Quality management/ Documentation

- Check Sheet (Tally Sheet)

- Cause-and-effect diagram ("fishbone" or Ishikawa diagram)

- Pareto chart (80/20 Rule)

- Critical Path Schedules

- The Eisenhower matrix

- Mind maps

- Checklists

- Logbook

- Batching of Tasks

7. How will you rate each of the factors on its importance in having a smooth workflow starting from 1 is Highest to lowest

- Resources

- Communication

- Documentation

- People- team

- People- others

- Cause and effect analysis

- Planning

- Subcontractor management

- Stakeholder Management

8. Rate the following on a scale of 1-10 as the most susceptible factor in errors in an architectural office:

- People

- Project manager

- Draftsperson

- Revisions issued by consultants/

- Lack of a clear establishment of responsibility within the team

- Methods

- Machines

- Material

- Measurements 
- Environment

9. What are the drafting and 3D modelling softwares used by your firm?

10. What are the BIM tools used by your firm? Does it include any of the these:

11. How does your firm adapt to new demands and insufficient sources?

In person interviews:

- What are the problems identified by your firm based on systematic workflow processes?

- How have your firm tackled those problems and by what means?

- How does your firm ensure uniformity (another word) in drawings within the office and on site?

- Communication and documentation management among - Architect, contractor, client

- "The problems that arise often occur during implementation, and seem to relate more to human factors than technological factors." Do you agree with this statement? If not, why?

- Did the lack of knowledge about devices and new technology hinder your ability to For a start-up:

- What were the problems faced by your firm during the initial setting-up process?

- Did you have the workforce to handle responsibilities and manage tasks at that time?

- If not, the how did you distribute the responsibilities with

the limited people

○ And Limited Resources

Design Process:

1. Tender or any source through which we came to know about the project

2. Site visit

3. Preliminary data collection, sketches

4. Contextual study and concept stage

5. Communication with the client

6. Communication within the office

7. Work distribution according to the strength and weakness

8. Work output management (interoffice)

9. Involvement of other support: fire tender, landscaping, construction details, lighting, drainage, etc. (intra office)

10. Coordination with them-- how? Documentation process?

11. Do you have a consultant. If yes, how is helping you to streamline work in office.

12. Communication with the client and site visit to finalize the design

13. Site work: construction phase

14. Documentation and communication process in the working site

15. Difference between both the experience?(inter and intra office, site)

16. Method of delivery

\section{PROJECT APPRAISAL STAGE- INTERVIEW QUESTIONS}

1. Project appraisal is the process of analyzing the technical feasibility and economic viability of a project proposal to finance their costs. It involves inception, feasibility, cost benefit analysis and strategic planning. How often your firm was involved in the project at this stage?

2. Who are all the stakeholders and other consultants, apart from architects, if any, involved at this stage ?

3. What are the problems faced by your firm during this stage :

a. In documentation 
b. In communication Inter office

c. In communication Intra office

4. Please rate the problems $1=$ No problem at all; $2=$ Moderate difficulties $; 3=$ extreme difficulties

5. What measures/tools do you make use of to overcome these problems?

6. What are some of the apparent causes of these problems you can name?

7. Conception and development of project brief is a part of this stage, what are the problems faced in translating the client demands into a brief and subsequently into a concept?

8. Cost benefit analysis for the project as well the definition of its budget is also done at this stage, Do you think any cost overruns are caused because of a faulty appraisal or do these overruns occur because of faults at other stages ?

9. Technical appraisal of the project determines the feasibility of the availability of the raw materials, equipment, skilled man power. Are cost overruns caused by both the cost and requirement of the mentioned things change till the completion of the project?

\section{PRE CONSTRUCTION STAGE- INTERVIEW QUESTIONS}

1. Project development is the first step of the pre-construction stage. Is your firm usually involved in the project appraisal stage? If not, do you see that as a drawback during the pre-construction stage?

2. Some firms hire a project manager at the time of the beginning of construction stage. The initiation of construction of the project highly depends upon a detailed feasibility analysis of the project carried out by the project manager. What are some of the measures adopted by your firm to assure compliance to the required criteria for a project to pass feasibility check?

3. Usually, how many teams are involved while detailing the methodology of construction? What is the frequency of revisions? Is everyone involved in the review process or only the teams directly involved in the construction stage?

4. Typically, both the architectural and engineering teams will work with the owner to create a design. How do you ensure that information is flowing freely between the design and engineering teams?

5. While working in teams, there is a need for constant reviews across teams. Without effective communication, the design process can be slow. What are some of the tools used by your firm for effective communication to streamline the design process and avoid cost delays?

6. Bar chart is one of the simplest tools for project scheduling and is used for both simple and complex projects. How does the structure and complexity of bar chart formation change from a small to a complex project?

\section{CONSTRUCTION STAGE- INTERVIEW QUESTIONS}

1. What are the causes of delay in project in construction stage?

2. What are the first steps of planning a construction project?

3. How do you know when a construction project is well-executed? What do you look for in quality control?

4. How do you structure a team for a construction product?

5. What are the biggest obstacles you have encountered during a project. What steps did you take to resolve them and how is two different projects can be handled simultaneously?

\section{COMMISSION AND HANDOVER STAGE- INTERVIEW QUESTIONS}

1. How can we get construction project handover procedure right, what are the risks involved?

2. What kind of data should be complianced after the project is complete as per specifications and designs? 